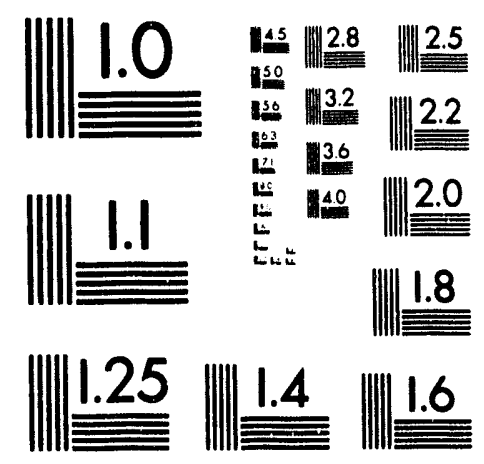



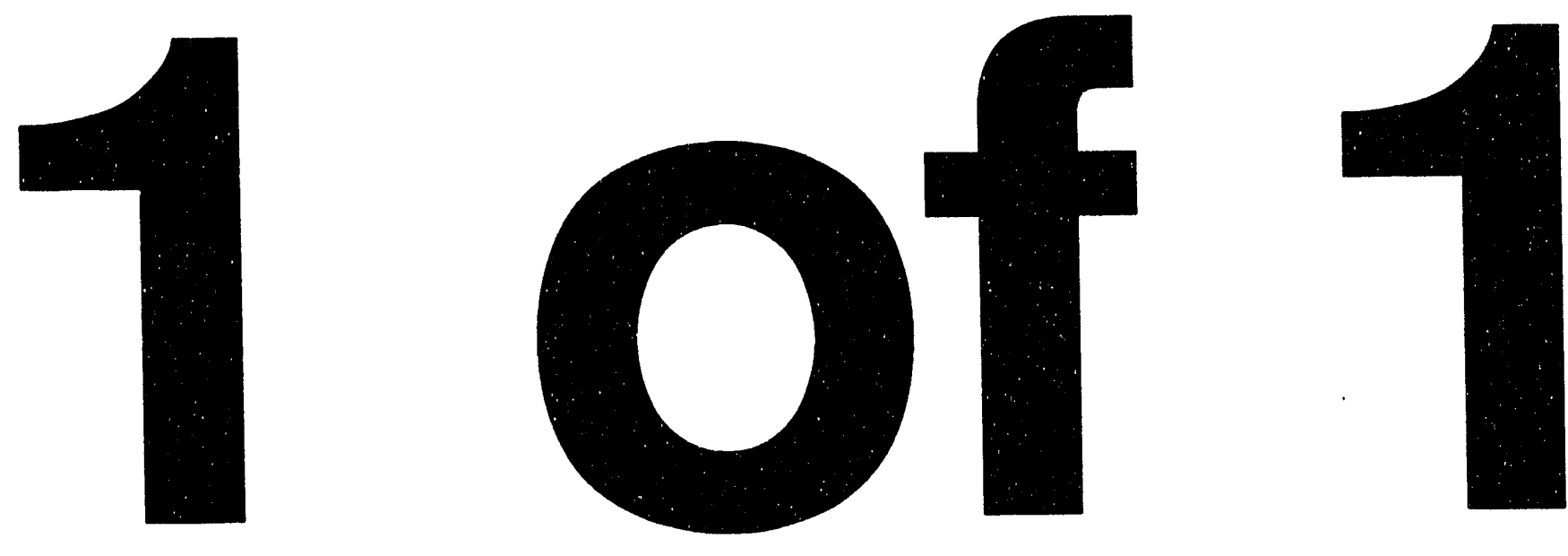
SAND93-7000

Distribution

Unlimited Release

Category UC-234

Printed May 1993

\title{
Tehachapi Solar Thermal System First Annual Report
}

\author{
A. Rosenthal \\ Southwest Technology Development Institute \\ P.O. Box 30001 Department 3SOL \\ Las Cruces, New Mexico 88003
}

Sandia Contract AC-7342

\section{ABSTRACT}

The staff of the Southwest Technology Development Institute (SWTDI), in conjunction with the staff of Industrial Solar Technology (IST), have analyzed the performance, operation, and maintenance of a large solar process heat system in use at the 5,000 inmate California Correctional Institution (CCI) in Tehachapi, CA. This report summarizes the key design features of the solar plant, its construction and maintenance histories through the end of 1991, and the performance data collected at the plant by a dedicated on-site data acquisition system (DAS).

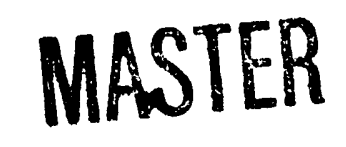




\section{CONTENTS}

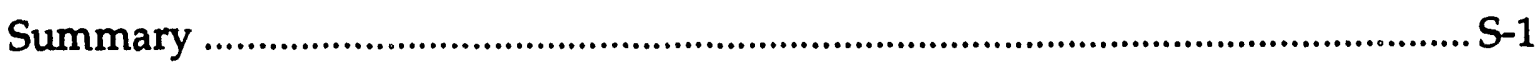

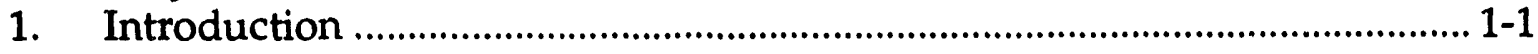

Background ……………................................................................................ 1-1

Existing Heating System …….................................................................. 1-1

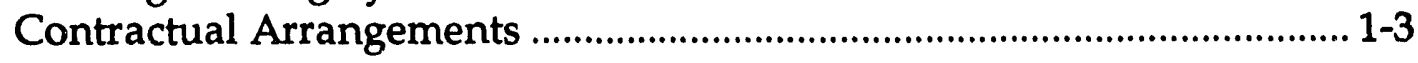

2. Solar System Components …………………................................................. 2-1

Concentrator Modules.......................................................................... 2-1

Layout of the Solar Field .................................................................................. 2-3

Drive System .................................................................................................... 2-3

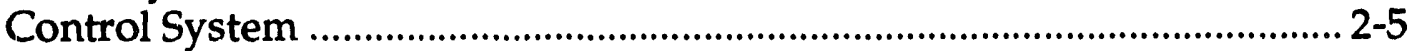

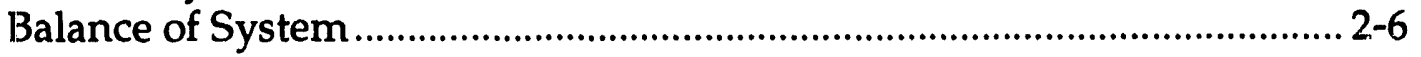

3. System Instrumentation ................................................................................ 3-1

Solar Monitoring Instruments ........................................................................ 3-1

Wind and Ambient Temperature Monitoring Instruments......................... 3-4

Flow Measurement ............................................................................................... 3-4

Circulating Fluid Temperature Measurement ................................................ 3-5

Datalogger and System Integration ................................................................. 3-6

4. System Maintenance ……………………........................................................ 4-1

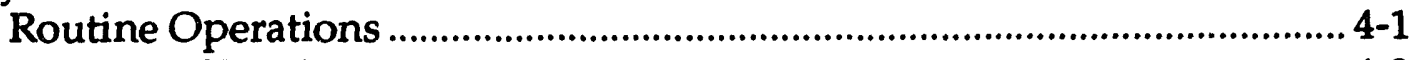

Reflector Cleaning .......................................................................................... 4-2

Wind Related Maintenance Actions ................................................................ 4-3

Controls Related Maintenance Actions............................................................. 4-4

System Interface Related Maintenance Actions .............................................. 4-4

Replacement of the Flexible Hoses .................................................................. 4-4

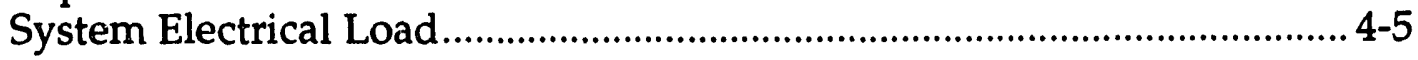

5. Performance Data .................................................................................... 5-1

Plant Availability ..................................................................................... 5-1

Plant Energy Production .................................................................................. 5-2

Plant Performance Versus Irradiance Range ................................................. 5-4

Clear Day Performance ....................................................................................... 5-5

6. Solar Resource and Wind Data .................................................................. 6-1

Wind Data ................................................................................................ 6-1

Ambient Temperature and Relative Humidity Data ..................................... 6-2

Insolation Data............................................................................................. 6-2

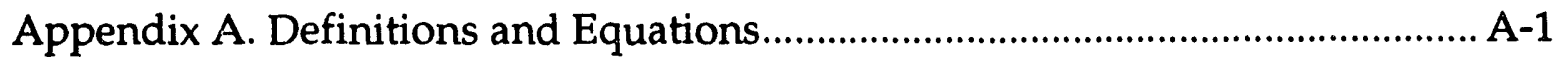




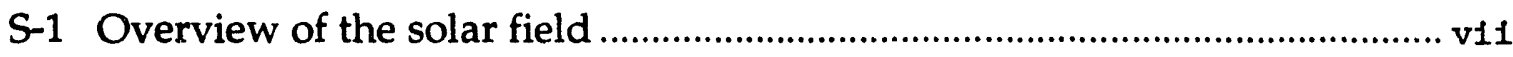

S-2 Insolation, energy output, and efficiency for July $14,1991 \ldots \ldots \ldots \ldots \ldots \ldots \ldots \ldots . . . \ldots \ldots$

2-1 Individual modules within the collector field ....................................... 2-1

2-2 Focus of the concentrator and the flexible hose .................................... 2-2

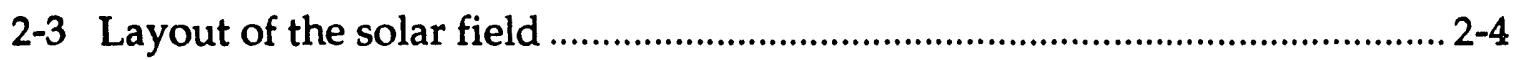

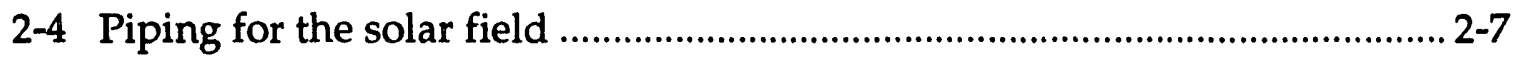

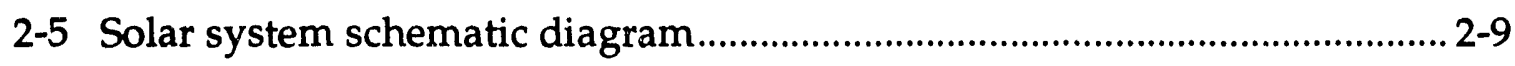

3-1 Solar monitoring instruments and weather tower.................................. 3-2

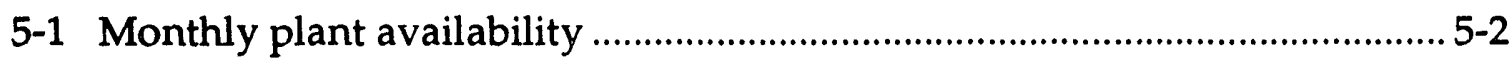

5-2 Monthly plant energy production and plane of array insolation................ 5-3

5-3 Monthly plant conversion efficiency …................................................... 5-3

5-4 Plant energy output and operating time versus irradiance range............. 5-4

5-5 Plant conversion efficiency versus irradiance range. ............................... 5-5

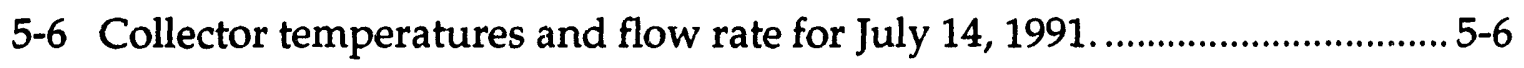

5-7 Insolation, energy output, and efficiency for July $14,1991 \ldots \ldots \ldots \ldots \ldots \ldots \ldots \ldots \ldots . . . . . . .6-6$

5-8 Collector temperatures and flow for November 5, 1991 .......................... 5-7

5-9 Insolation, energy output, and efficiency for November 5, 1991............... 5-8

6-1 Monthly average and maximum wind speeds ......................................... 6-1

6-2 Monthly average ambient temperature and relative humidity ...................6-2

6-3 Monthly totals for direct normal, plane of array, total horizontal, and diffuse irradiance.

\section{Tables}

1-1 Boiler Plant Natural Gas Use and Costs ................................................. 1-3

3-1 Tehachapi Das Input Signals ....................................................................... 


\section{Summary}

A solar process heat system has been in use at the 5,000 inmate California Currectional Institution (CCI) in Tehachapi, CA, since early 1991. This report summarizes the key design features of the solar plant, its construction and maintenance histories through the end of 1991, and the performance data collected at the plant by a dedicated on-site data acquisition system (DAS).

An overview of the solar field is shown in Figure S-1.

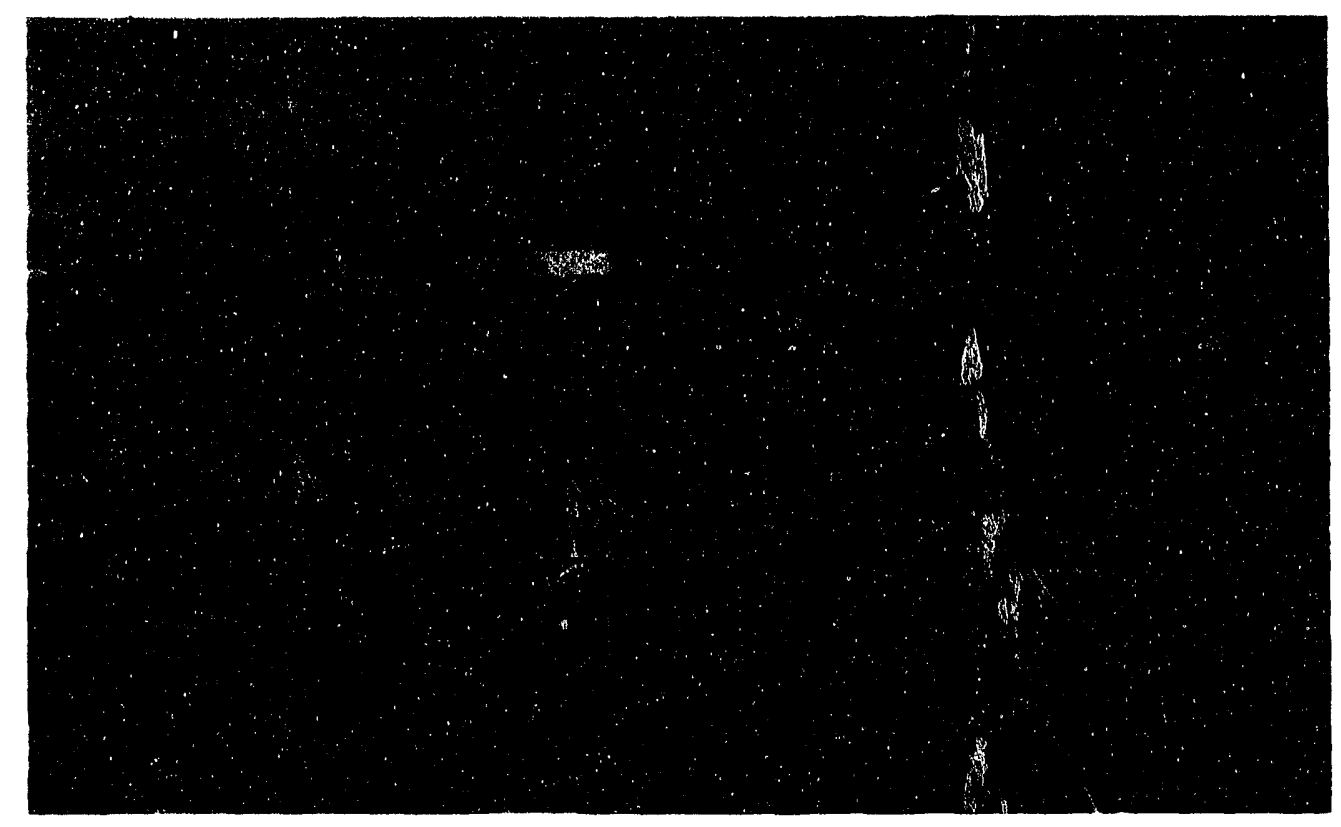

Figure S-1. Overview of the solar field

The system utilizes parabolic trough solar collectors designed and built by Industrial Solar Technology (IST), of Denver, CO, with a total collector field aperture area of $28,800 \mathrm{ft}^{2}\left(2,677 \mathrm{~m}^{2}\right)$. The system provides heat to a $240^{\circ} \mathrm{F}\left(116^{\circ} \mathrm{C}\right)$ pressurized water loop that distributes energy throughout the Institution for showers, kitchens, laundry, and space heat. In addition, the system provides thermal energy to a separate 
domestic hot water load. At peak solar conditions, the system is designed to meet about $80 \%$ of the summertime thermal demand.

The solar thermal system is privately owned. No state monies were used for its construction. Under a 30-year Energy Purchase Agreement, CCI agreed to provide the land for the solar collectors and associated piping. The system owner retains responsibility for all system maintenance and for the cost of the system's liability insurance. The delivery of heat from the solar system is accurately measured using a commercially available BTU meter with monthly billings provided to CCI. Solar energy is sold to $\mathrm{CCI}$ at a savings to the state of $5 \%$ compared to the equivalent amount of energy supplied by natural gas. Energy sales provide a long-term payback to the system owners of the $\$ 625,000\left(\$ 21.70 / \mathrm{ft}^{2}, \$ 233 / \mathrm{m}^{2}\right)$ purchase price.

Fabrication of system components began in June 1990, and installation was completed by late October 1990. The DAS was installed in February 1991. System performance reporting began on March 1, 1991 while the system was in its startup phase. During the startup phase, problems associated with the new system hardware were identified and corrected by IST personnel. These included: misalignment of the collectors as a result of wind and snow loading; a failed flow switch that kept the field in stow position for several days; and corrosion of some of the tracker controller's sensor wires. Also during this period, a system design flaw associated with the flexible hoses connecting adjacent collectors was identified. A program to improve the design of these hoses was subsequently undertaken by IST and the Solar Thermal Design Assistance Center (STDAC) at Sandia National Laboratories (SNL). The program resulted in redesigned flexible hoses that were successfully retrofitted to the system in November and December of 1991.

Plant availability improved steadily throughout the startup period that ran from March through June. Availability for July was near $100 \%$. Availability for the balance of the year was high except during periods of strong winds, which forced the collectors 
to remain in stow position, lost time caused by the retrofit of the flexible hoses and infrequent shutdowns for maintenance in the boiler room. Solar system maintenance is carried out by local personnel employed by IST. Routine activities are mainly inspection of the system components and washing of the collectors' reflective surface to maintain performance.

In the 10-month period from March through December 1991, the plant delivered a total of 3,673 MMBtu of thermal energy with a peak hourly delivery of 4.1 MMBtu recorded during June. Solar-to-thermal conversion efficiency of approximately $40 \%$ is common for hours of clear sky operation.

Figure S-2 illustrates typical summer day performance for the plant.

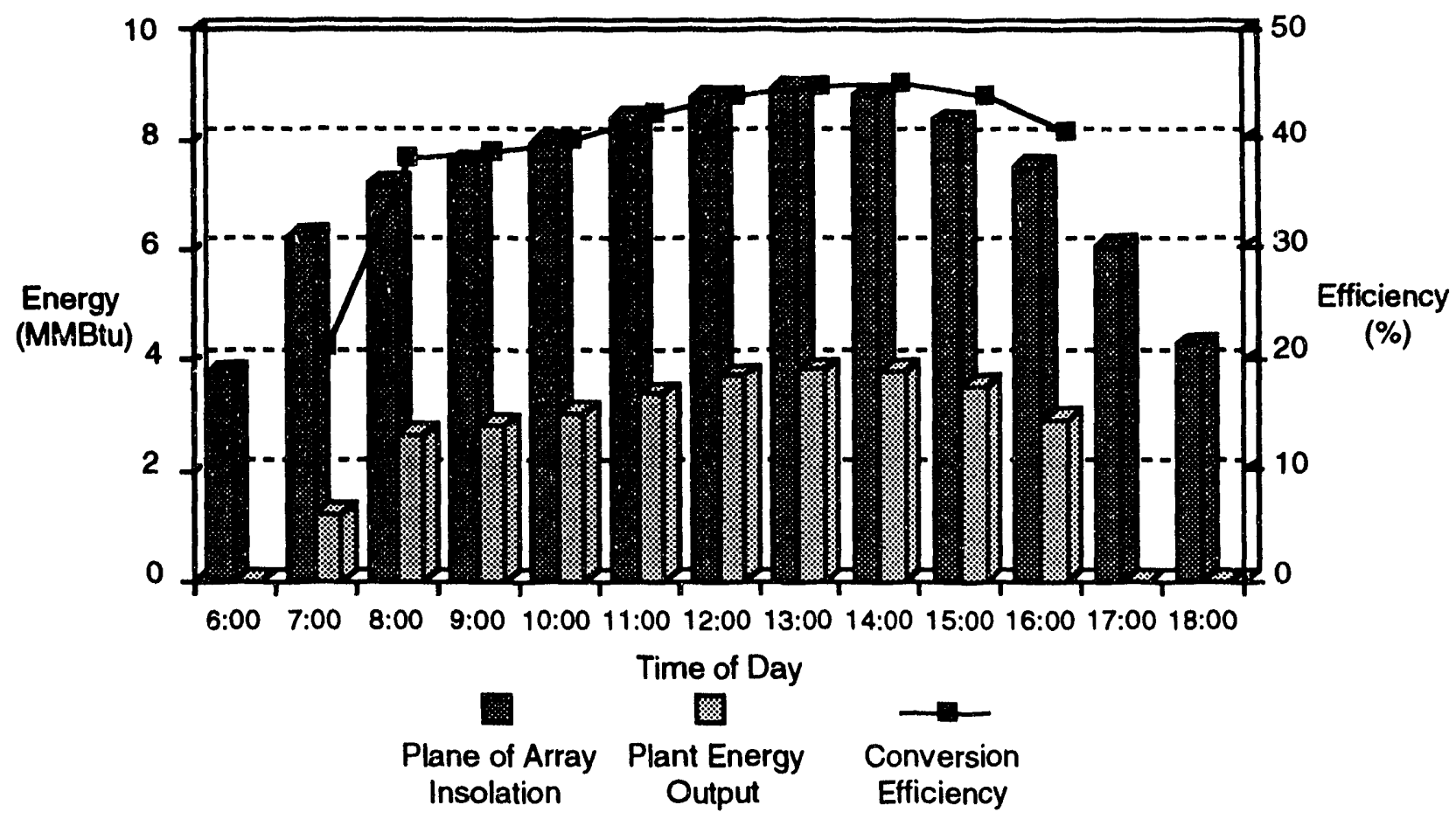

Figure S-2. Insolation, energy output, and efficiency for July, 141991

On July 14 , the solar system ran for 9.5 hours, delivering a total of $31 \mathrm{MMBtu}$ $(9,100 \mathrm{kWh})$ of heat. The maximum hourly conversion efficiency of sunlight to delivered heat was $43.5 \%$. Energy delivery for the day was reduced by the early 
shutdown of the plant. The retrofit of the flexible hoses now allows the system to run longer at the end of each day.

Tehachapi is a site that is subject to long periods of sustained high winds. Peak system efficiency is reduced by high winds because they increase thermal losses from the system and promote soiling of the collectors' reflective surfaces. In addition, excessive winds frequently force the system to shut itself down and remain in stow position. To date, the system has survived winds in excess of $80 \mathrm{mph}$. 


\section{Introduction}

\section{Background}

The California Correctional Institution (CCI) is located in Tehachapi, CA, a small town in a mountain pass at an elevation of $4000 \mathrm{ft}(1220 \mathrm{~m})$ between Bakersfield in the San Joaquin Valley and Mojave in the desert bearing that name. Tehachapi calls itself "the land of four seasons," where, unlike much of California, its mountain location creates a true winter environment, and snowfalls are common. In the summer, temperatures are milder than in nearby communities at lower elevations. Its location at the foot of a mountain chain between the confined Central Valley and the Mojave Desert produces conditions for nearly continuous air flow. Taking advantage of such geography, Tehachapi is the site for thousands of wind turbines. However, wind storms are frequent during the winter, and the Santa Anna winds from the east can reach very high velocities.

The CCI is a state facility housing over 5,000 inmates, supervised around the clock by a support and security staff of almost 2,000. The Institution houses all categories of security risks in facilities spread over several square miles. The energy needs of the Institution are considerable. Thermal energy is used for cooking, washing in kitchens and washing in laundries, showers, and space heating.

\section{Existing Heating System}

Most of the thermal energy used at the $\mathrm{CCI}$ is delivered from a central boiler plant. Natural gas burned in three boilers generates saturated steam at a pressure of 8.3 bar (120 psig). Two of the boilers were built in 1964 and have a rated heat input of 8.6 MW (29.19 million Btu/h) each. The third boiler was built in 1984 and has a rated hrat 
input of 9.5 MW (32.479 million Btu/h). Thus, the total rated input of all three boilers is 26.6 MW (90.9 million Btu/h). The number of boilers in use varies depending on the thermal load. In typical winter operation, one boiler is at full load, a second is varying in output to meet the load, and the third is on standby. In summer, one boiler is sufficient to meet the load, a second is on standby, and the third can be shut down.

Most of the steam produced by the boilers is transferred through a heat exchanger to a pressurized water loop that circulates for several miles between the $\mathrm{CCI}$ buildings. The temperature of this loop as it leaves the boiler room varies between 220 and $240^{\circ} \mathrm{F}\left(104\right.$ and $\left.116^{\circ} \mathrm{C}\right)$ depending on the time of the year. The boilers also provide heat directly to the laundry for pressing clothes, and directly to a DHW loop that services a nearby detention unit. In addition, the boilers meet their own parasitic thermal needs for feed water deaeration and makeup water heating.

Natural gas supplying the steam boilers is metered separately. To reduce purchase costs, the gas is supplied on an interruptible basis. Through the end of 1990, the gas was supplied by Southern California Gas (SCG) Company. Since that time, the state of California has negotiated contracts with independent suppliers to further recuuce its natural gas costs. Currently, most of this gas comes from Canada. The independent suppliers provide CCI with a bill for the cost of the gas, while SCG supplies another bill to cover the costs of meter reading and of transporting the gas through its pipeline network. Table 1-1 shows the amount of energy flowing through the meter at the boiler, and the associated costs for the years 1986 through 1989 in comparison to the same data for 1991. 
Table 1-1. Boiler Plant Natural Gas Use and Costs

$\begin{array}{cccc}\text { Time Period } & \begin{array}{l}\text { Energy Use } \\ \text { (Million Btu) }\end{array} & \begin{array}{c}\text { Energy Cost } \\ (\$)\end{array} & \begin{array}{c}\text { Unit Energy Cost } \\ (\$ / \text { million Btu) }\end{array} \\ 1986 & 127,856 & 494,417 & 3.86 \\ 1987 & 147,084 & 538,781 & 3.66 \\ 1988 & 158,875 & 625,551 & 3.94 \\ 1989 & 133,662 & 498,559 & 3.73 \\ 1991 & 122,949 & 396,838 & 3.22\end{array}$

Natural gas use in 1991, the first full year of solar system operation, was down from previous years. The cost of natural gas also declined, even in current dollar terms. Thus, the decline in real dollars, adjusted for inflation, would be larger still.

The numbers also indicate the substantial size of the thermal load. Average daily natural gas consumption is about 356 million Btu, and the average hourly consumption is about 14.8 million Btu. This compares with the peak loading capacity of the three boilers of 90.9 million Btu/h.

\section{Contractual Arrangements}

United Solar Technologies (UST) of Santa Cruz, CA, served as the developer for the solar thermal system at the CCI. The system supplier, IST of Denver, CO, provided technical, marketing, and financial analysis capability to the development effort.

In 1986, IST installed a solar thermal system at the Adams County Detention Facility in Brighton, $\mathrm{CO}$. The company had identified prisons as favorable sites for solar applications. Typically, prisons have a substantial, relatively constant, year-round load for thermal energy at a fairly low temperature. In addition, their locations are often remote from other developments and can provide the area necessary to site a large solar field. Acting on this information, UST personnel, in consultation with the California Department of Corrections in Sacramento, identified CCI as a potential site for a solar thermal energy system and UST made its first visit to Tehachapi in July 1988. 
A long period of negotiations ensued requiring numerous meetings in Sacramento with the Department of Corrections, the California Energy Commission (CEC), and the Department of General Services, as well as visits to the site to meet with $\mathrm{CCI}$ persornel and to gather technical data. Also involved were the legal and financial advisors of the investor who would ultimately own the CCI solar system. Finally, on April 22, 1990 (Earth Day 1990), an Energy Purchase Agreement was signed between UST and the Department of Corrections.

The Energy Purchase Agreement to supply solar energy to CCI has a term of 30 years. CCI agreed to provide the land to site the solar collectors and the space for the piping runs and solar equipment. The system owner is responsible for the maintenance of the solar system and for insuring the equipment for liability and property damage.

As laid out in the contract, the delivery of heat from the solar system is accurately measured using a commercially available BTU meter, and the monthly billings are provided to $\mathrm{CCI}$. The cost of the solar energy supplied is based on the cost of natural gas used during the billing period and the efficiency of the existing boilers. The value of the boiler efficiency used in the contract was a topic of much discussion, and the contractually agreed value of $75 \%$ is regarded by UST and IST as high. This contention is based on the fact that the nameplate efficiency rating of the boilers is $80 \%$ when new, operating at full load, under ideal conditions at sea-level, and without taking into account the efficiency loss due to blowdown. In contrast, two of the three boilers at $\mathrm{CCI}$ are almost 30 years old, operate at only a fraction of their rating most of the time, the site is at an elevation of $4,000 \mathrm{ft}(1,220 \mathrm{~m})$, and blowdown to maintain water quality is a feature of all operating systems.

An electric meter was installed as part of the system to record electricity use. The cost of such use is refunded to $\mathrm{CCI}$ and is calculated based on the meter reading and the average unit cost of power billed to $\mathrm{CCI}$ by the electric utility, Southern California 
Edison. As a financial incentive to install the system, a rebate of $5 \%$ of the energy billings was provided to the state.

After signing of the Energy Purchase Agreement, IST began fabrication of system components. Items that could be readily shipped were fabricated in IST's Denver plant. Site work began at CCI in early June 1990. By early July, a factory was set up in Tehachapi to assemble the solar concentrators. The system was started up at the end of September. Final construction details extended the completion date to late October.

UST provided construction financing to IST. UST arranged to receive these funds under a small business loan program administered by the CEC. A short term loan at the rate of $5 \%$ was provided in response to an application by UST describing the $\mathrm{CCI}$ project and the receipt of collateral to ensure repayment of the full amount.

When the system was fully operational, UST sold the system to a firiancial investor for $\$ 625,000\left(\$ 21.70 / \mathrm{ft}^{2} \$ 233 / \mathrm{m}^{2}\right)$, and made the final system payment to IST. IST obtained an agreement with the investor to maintain the system in return for $8 \%$ of the energy revenues. 


\section{Solar System Components}

\section{Concentrator Modules}

The basic unit of the solar system is the parabolic concentrator module. These measure $7.5 \mathrm{ft}(2.28 \mathrm{~m})$ wide by $20 \mathrm{ft}(6.1 \mathrm{~m})$ long, for a gross aperture area of $150 \mathrm{ft}^{2}$ $\left(13.9 \mathrm{~m}^{2}\right)$. The module is fabricated entirely of aluminum and weighs approximately $160 \mathrm{lb}(73 \mathrm{~kg})$ or $1.1 \mathrm{lb} / \mathrm{ft}^{2}\left(5.2 \mathrm{~kg} / \mathrm{m}^{2}\right)$. The parabolic surface of the concentrator is covered with a reflective film manufactured by $3 \mathrm{M}$ Company, know as SA-85. The specular reflectance of SA-85 in the pristine condition is about $83 \%$. Figure $2-1$ shows individual modules within the collector field.

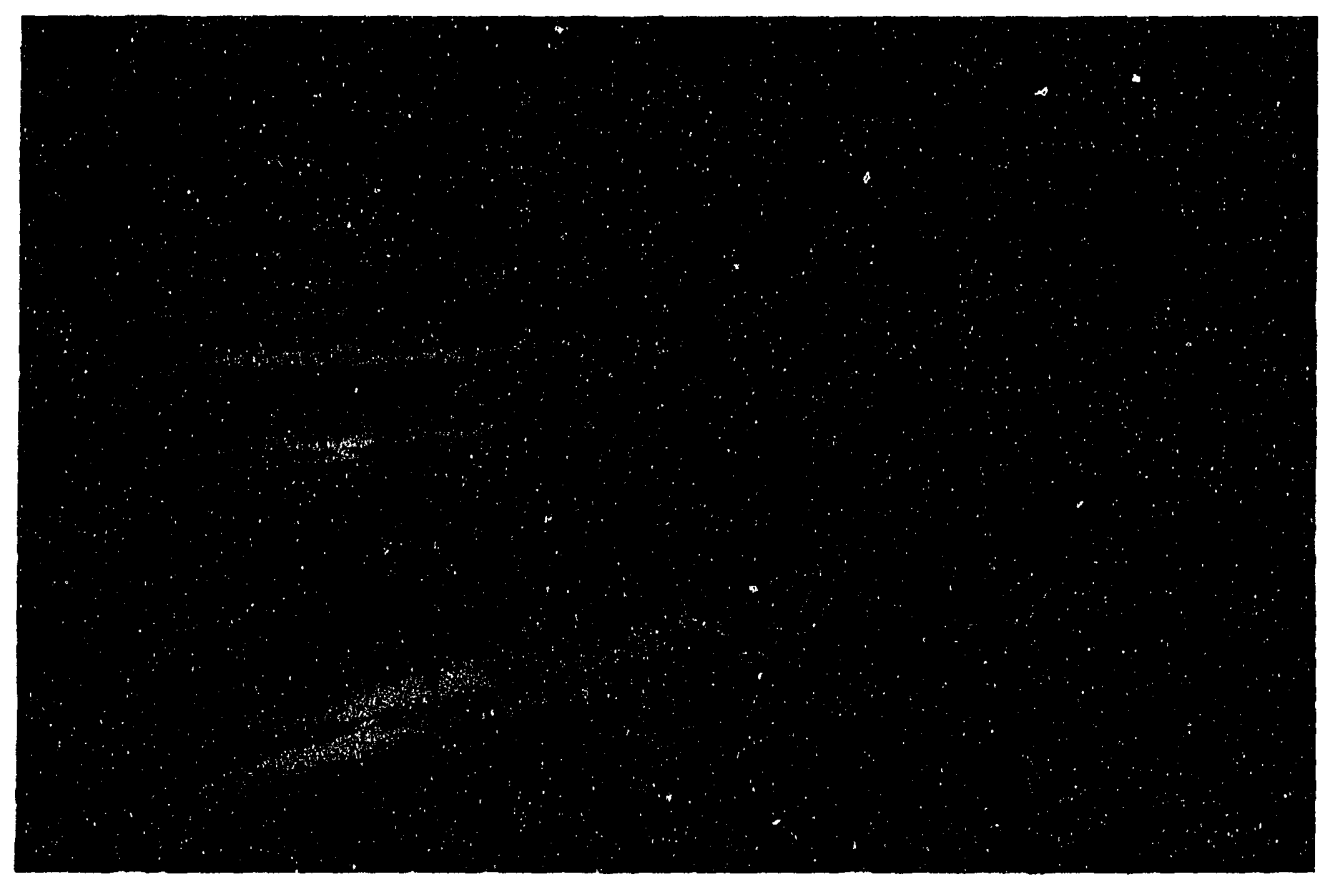

Figure 2-1. Individual modules within the collector field

The receiver located at the focal point of the concentrator uses a 2-in. (50.8-mm) O.D. steel absorber tube coated with a black chrome selective surface. A 3-in. (75-mm) 
O.D. borosilicate glass tube surrounds the absorber to minimize heat loss. When new, the selective surface had an absorptance of about 0.95 and an emittance at operating temperature of about 0.25 . The transmittance of the glass is about 0.91 . Each receiver assembly is slightly over $10 \mathrm{ft}(3.3 \mathrm{~m})$ long. Thus, two assemblies span each concentrator modvle. The absorber tubes are welded together. Figure 2-2 illustrates the focus of the concentrator and the flexible hose that attaches the moving absorber to the fixed piping system.

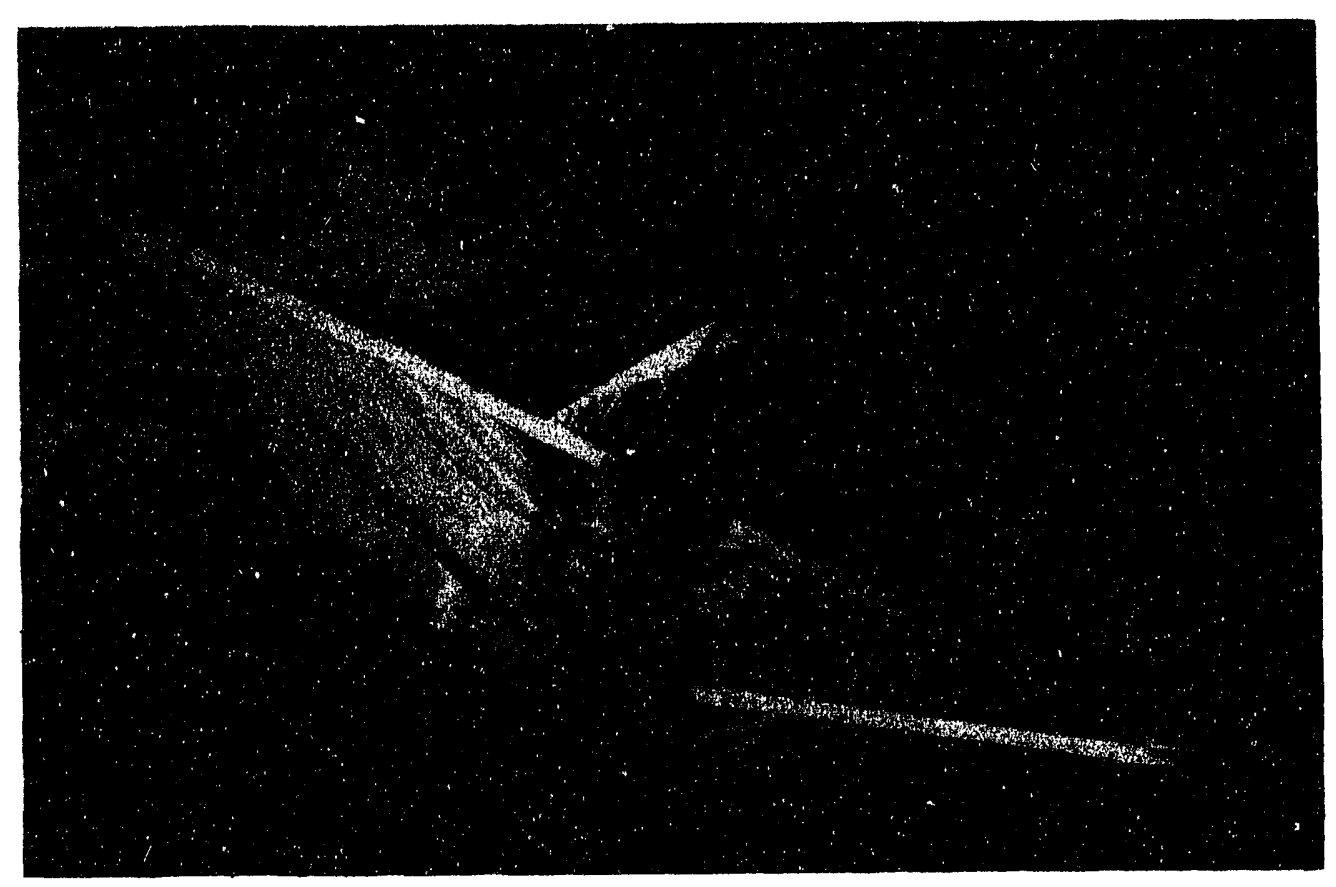

Figure 2-2. Focus of the concentrator and the flexible hose 


\section{Layout of the Solar Field}

The CCI solar system is made up of 192 concentrator modules for a total gross area of $28,800 \mathrm{ft}^{2}\left(2677 \mathrm{~m}^{2}\right)$. The solar system does not incorporate thermal storage because of the expense of storing energy at temperatures above the boiling point of water. The system is sized to meet the minimum, summertime thermal load so that at no time must the system be shut down because of excess energy delivery. As shown in Figure 2-3, the modules are arranged in 16 rows of 12 modules each. The concentrator row to row spacing is $20 \mathrm{ft}(6.1 \mathrm{~m})$, except at the center where the spacing is $31 \mathrm{ft}(9.5 \mathrm{~m})$. This larger spacing was necessary to accommodate a utility right-of-way for a power line running down the center of the field, and a power pole and guy wires located exactly in the center of the field.

The presence of the power line and a road to the west side of the solar field dictated the orientation of the field. The axis of the collectors runs approximately NW to $\mathrm{SE}$, actually $35^{\circ}$ off true north.

The solar field is enclosed by a chain-link fence that measures $279 \mathrm{ft}(85 \mathrm{~m})$ in the near north-south, and $346 \mathrm{ft}(105 \mathrm{~m})$ in the near east-west direction, enclosing an area of 2.2 acres ( 0.9 hectares). Access is through a drive-in gate at the center of the north side, and through a walk-in gate on the south corner, nearest to the boiler room. $\mathrm{CCI}$ security specifications required that the fence be $10 \mathrm{ft}(3 \mathrm{~m})$ tall topped by three strands of barbed wire. The fence is covered with $9 \mathrm{ft}(2.7 \mathrm{~m})$ of netting to act as a wind break to limit the impact of wind on the solar concentrators.

\section{Drive System}

The parabolic concentrators track the sun about a single axis. Three modules are connected together on either side of a central drive pylon. Six other interior pylons provide support for the row of six modules. The pylons are fabricated of steel and are bolted to reinforced concrete caissons that are embedded in the ground. 


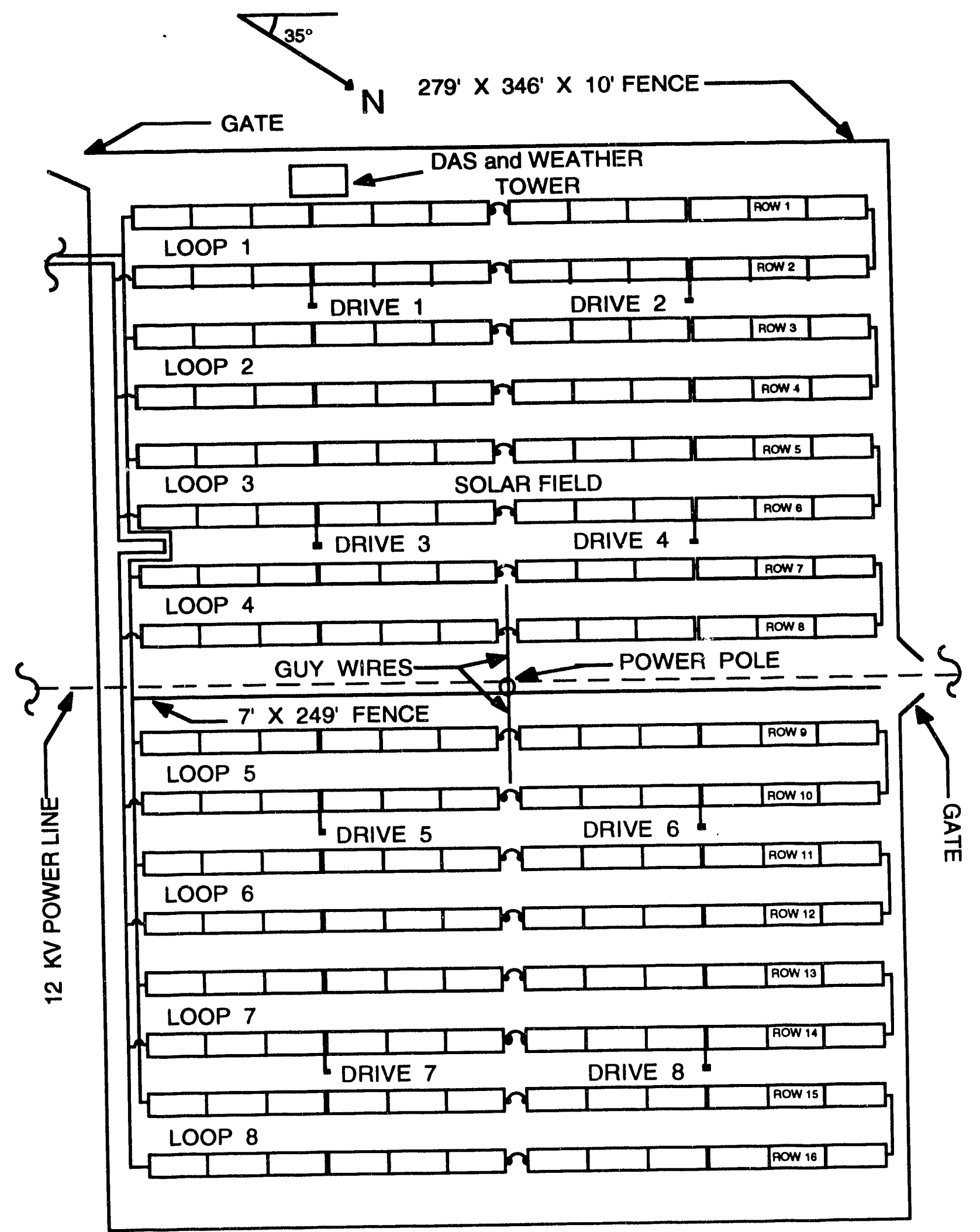

Figure 2-3. Layout of the solar field 
IST has developed a "multi-row" drive system to reduce the cost and to increase the reliability of the tracking system. Instead of using a controller and a drive for each module row, four rows are driven together using a single drive motor and controller.

\section{Control System}

The solar system is controlled by the Honeywell Flux-line system, manufactured by IST under an exclusive license from Honeywell. The Honeywell system comprises two different controllers-both incorporating programmable microprocessor logic.

A single master controller monitors system-level functions. Integral to this controller are the start up sensor and a wind anemometer, which monitor solarradiation intensity and wind speed, respectively. In addition, using external switching instrumentation, the controller also ensures that flow of the collector fluid, system outlet temperature, and collector fluid level in the expansion tank are all within satisfactory limits. If these parameters are within the specified limits, solar radiation is above a preset threshold, and the wind speed is below a preset threshold, then the master controller provides an authorization signal to the eight local controllers that perform tracking of the concentrators.

The shutdown or "stow" position of the collectors is with the reflective surface nearly facing the ground. In this orientation, the collectors are protected from soiling, and their profile to the wind is decreased. When an authorization signal from the master controller is received by a local controller, the drive motor is activated to drive the collectors out of stow in search of the sun. Sun sensors for the local controllers are located on each side of the receiver. These are only sensitive to concentrated sunlight, and thus avoid many of the problems associated with sensors of the shadow band type. Shadow band sun trackers must be sensitive to low light intensities and can be fooled by bright spots in clouds or extraneous reflections. 
Depending on where the sun is located, the collectors will come into focus in about one or two minutes of motion. As soon as concentrated sunlight is detected at the receiver, the motion of the collectors will change to a series of small increments until the voltage output of the sensors on each side of the receiver is equalized. The output of the sensors is constantly monitored, and slight corrections in the orientation of the collectors are made as appropriate to maintain the collectors in focus as the position of the sun changes.

Both the master and local controllers employ time delays to avoid cycling of the collectors in the event of transients, such as cloud passage or wind gusts. However, in the event of a lack of sun for a given period or any unsafe operating condition, the collectors turn off by driving to the stow position. Abnormal conditions, such as field over temperature or no flow, "lock out" the solar system and require manual intervention for restart.

\section{Balance of System}

Unlike much of California, Tehachapi experiences severe winter weather with long periods of subfreezing temperatures. To cope with these conditions, the collector fluid is an anti-freeze mixture of ethylene glycol and water. This is pumped through the solar system at a flow rate of about $154 \mathrm{gpm}(5831 / \mathrm{min})$ using a centrifugal pump located on the second floor of the boiler room.

Figure 2-4 shows the piping run from the boiler room to the solar field. The first $350 \mathrm{ft}(106.7 \mathrm{~m})$ of the field inlet and return piping is overhead, crossing over the entrance to a prison yard and two perimeter roads. The final $150 \mathrm{ft}(46 \mathrm{~m})$ of the pipe runs inside the perimeter fence at ground level and includes a " $Z$ " expansion bend. 


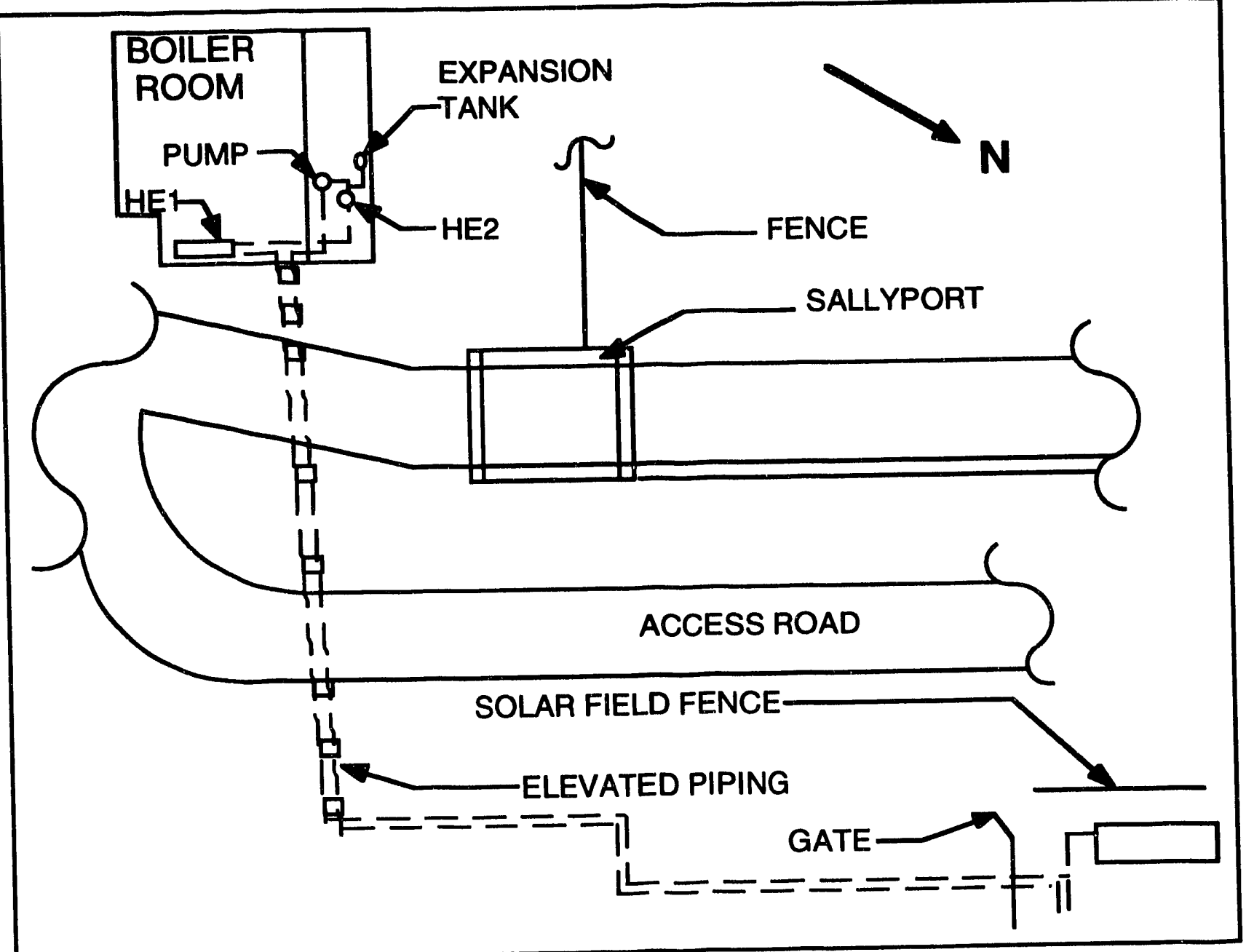

Figure 2-4. Piping for the solar field

All of the piping in the solar system is made of steel. Fittings have a rating of 150 psig (10.3 bar). Piping larger than 2 in. $(50.8 \mathrm{~mm})$ is welded or flanged. Small piping is threaded. Piping is insulated with fiberglass covered with an aluminum. jacket. Insulation thickness is 2 in. $(50.8 \mathrm{~mm})$ for piping 2 in. $(50.8 \mathrm{~mm})$ and larger, and $1.5 \mathrm{in}$. $(38.1 \mathrm{~mm}$ ) for smaller diameters. The main header piping has a 3 in. diameter. The field header serves the collectors through eight U-loops. Take-offs from the field header are 1.25 in. $(38.1 \mathrm{~mm})$, whereas the header itself is stepped in sizes from 3 in. to 1.5 in (76.2 $\mathrm{mm}$ to $38.1 \mathrm{~mm}$ ).

The flow rate through each collector U-loop or "delta T" string is nominally 19.25 gpm $(731 / \mathrm{min}$.). Valves are provided at the inlet and outlet of each string for isolation 
purposes. Inside each of these valves is a pressure relief valve. Flexible hoses connect the moving absorber tube to the fixed piping. These flexhoses have an inner convoluted stainless steel hose that carries the collector fluid. Surrounding this hose is an interlocked stainless steel hose. The annular space between the two hoses is insulated with fiberglass.

Figure 2-5 is a schematic of the solar system showing major equipment, controls, and instrumentation. The hot fluid from the solar field passes through two shell and tube heat exchangers. The first and larger exchanger is mounted on the wall of the boiler room about $18 \mathrm{ft}(5.5 \mathrm{~m})$ above the floor, the only location available to site this exchanger. The solar system preheats the pressurized water loop flowing through the tube side of this heat exchanger before additional heat is added, if necessary, with heat transferred from the steam supplied by the natural gas-fired boilers. The second solar heat exchanger is a double-walled unit that transfers heat to a domestic water loop heated conventionally with two steam-to-water heat exchangers. This second heat exchanger is mounted vertically, again to save space, on the second floor of the boiler room. Also located on the second floor are the expansion tank and, downstream of the second heat exchanger, the circulating pump. 


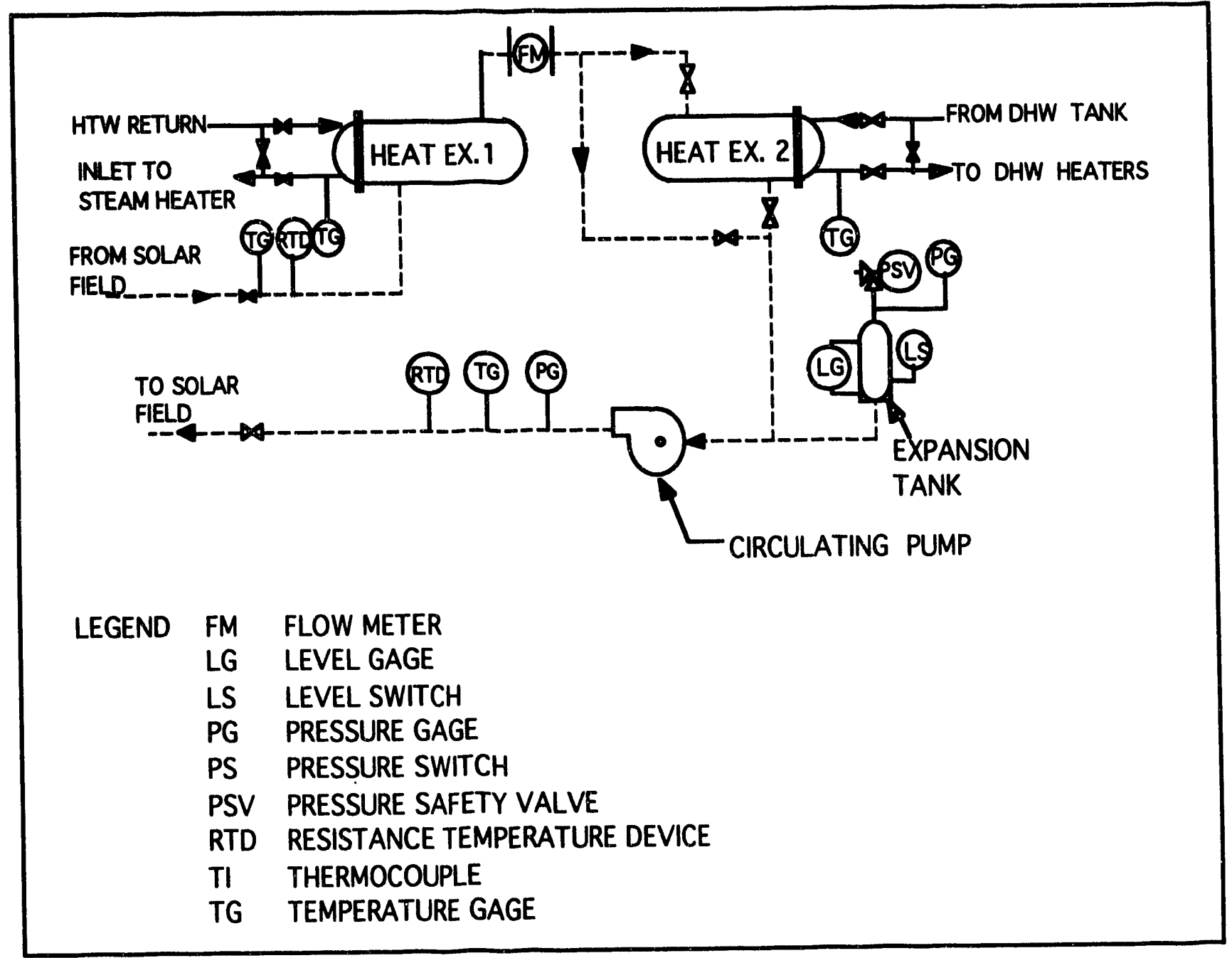

Figure 2-5. Solar system schematic diagram 
2-10 


\section{System Instrumentation}

The SWTDI, under contract to the STDAC at SNL, designed and installed the DAS used at Tehachapi. The design goals for the DAS were that it monitor the available Tehachapi solar resource, the solar plant's energy production and conversion efficiency, and other ambient conditions necessary for full characterization of plant performance. Table 3-1 presents an overview of the signals monitored by the DAS and the sensors used for each.

Table 3-1. Tehachapi Das Input Signals

Signal Description
Horizontal Irradiance
Direct Normal Irradiance
Diffuse Irradiance
Relative Humidity
Ambient Temperature
Wind Speed
Wind Direction
Flow

Inlet Fluid Temperature Outlet Fluid Temperature

\section{Sensor}

Eppley Precision Spectral Pyranometer (PSP) Eppley Normal Incidence Pyrheliometer (NIP) Eppley Shadow Band Stand and PSP Phys-Chem PCRC-11 RH Sensor Fenwal Electronics UUT51J1 Thermistor Met-Une 014A Wind Speed Sensor Met-One 024A Wind Direction Sensor Orifice plate and Rosemount 1151DP4E12M2 Flow Transmitter Omega NB1-Cass-144-6 Type E Thermocouple Omega NB1-Cass-144-6 Type E Thermocouple

This section is divided into four categories: Solar Monitoring Instruments, Wind and Ambient Temperature Monitoring Instruments, Plant Performance Monitoring Instruments, and Datalogger and System Integration.

\section{Solar Monitoring Instruments}

The solar monitoring instruments were selected to fully characterize the solar resource at the Tehachapi site with respect to total horizontal, direct normal, and diffuse 
irradiance. All solar monitoring instruments are mounted on top of a 11-ft (3.4-m) high platform located near the west end of the collector field. The weather tower with the solar monitoring instruments is shown in Figure 3-1.

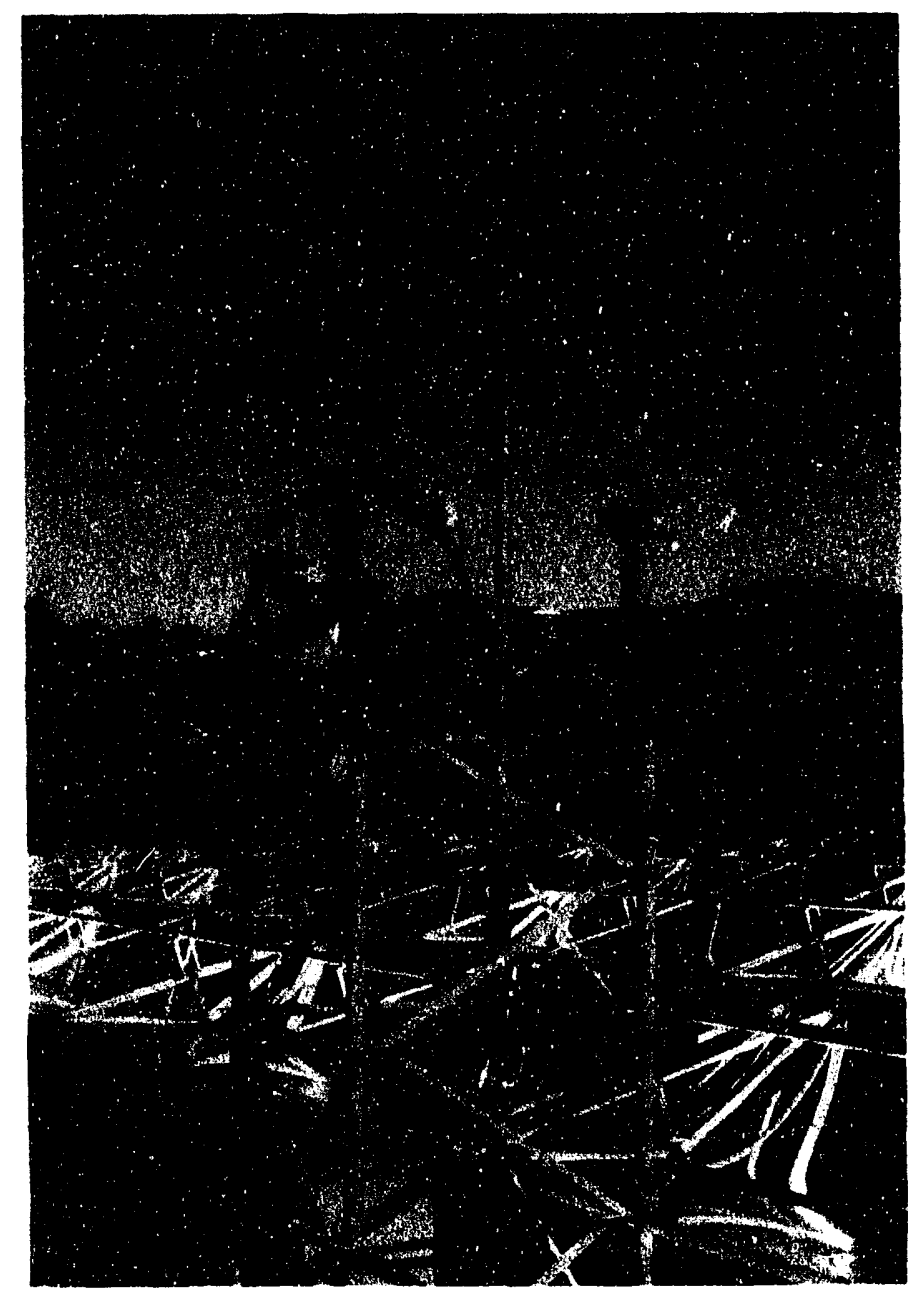

Figure 3-1. Solar monitoring instruments and weather tower

This is a solar concentrator system capable of utilizing only the direct (beam) radiation for the generation of process heat. For this reason, it is necessary to measure the direct irradiance falling on the array in order to assess system performance and to calculate system efficiency. The additional measurement of the diffuse and total horizontal irradiance enable quality assurance testing of the direct irradiance data and complete characterization of the site's solar resource. 
The Eppley Laboratory, Inc. PSP was selected to measure the total horizontal irradiance. This is a broadband instrument that is widely used for the measurement of the sun's total (direct plus diffuse) irradiance in a horizontal plane. The PSP comprises a circular multijunction thermopile (copper-constanten), which is temperature compensated to reduce temperature dependence to $1 \%$ over the range 21.6 to $129.6^{\circ} \mathrm{F}$ $\left(-20\right.$ to $\left.+40^{\circ} \mathrm{C}\right)$. The instrument uses two ground and polished concentric hemispheres of Schott optical glass to cover the thermopile. The ins'zument demonstrates a cosine resp. onse of $\pm 1 \%$ from $0.70^{\circ}$ zenith angle.

The Eppley PSP and shadow band stand were selected for the measurement of diffuse irradiance. The shadow band stand uses a metal shading ring to prevent the sun's direct beam radiation from striking the PSP. Adjustments need to made to the ring every few days to compensate for the sun's changing declination angle.

The Tppley NIP was selected to measure the sun's direct normal (beam) radiation. The sensitive element of the NIP is a wire wound thermopile with a thermistor temperature compensating circuit. The thermopile is mounted at the base of a collimateci brass tube, the aperture of which bears a ratio to its length of 1 to 10 . The aperture angle is $5.7^{\circ}$ so the detector actually receives radiation from the sun and from an area of the circumsolar sky two orders of magnitude larger than the sun. The NIP is mourited on a Licor LI-2020 two-axis sola' tracker. This tracker is microprocessor based and, after initial alignment, tracks the sun to within one degree per month without the need for realignment. 


\section{Wind and Ambient Temperature Monitoring Instruments}

The DAS at Tehachapi measures wind speed and direction, ambient temperature, and relative humidity. All of these sensors are mounted on an $8-\mathrm{ft}(2.4-\mathrm{m})$ pole that projects above the north side of the instrument platform Wind Speed is measured with a Met-One 014A wind sensor. This is a 3-cup anemometer. When the cups rotate, a turning magnet assembly causes a reed switch to close. There are two contacts (switch closures) per revolution and the frequency of closure is linear from the anemometer's threshold speed of 1.47 to $147.6 \mathrm{ft} / \mathrm{s}(0.447$ to $45 \mathrm{~m} / \mathrm{s})$. Wind direction is measured with a Met-One 024A wind direction sensor. This instrument has a counterbalanced wind vane coupled to a precision, low-torque potentiometer. Excitation voltage is provided by the datalogger.

Ambient temperature and relative humidity are monitored at the site with a Campbell Scientific, Inc., 207 probe. This probe has two measuring instruments: a Fenwal Electronics UUT51J1 thermistor to measure temperature and a Phys-Chem Scientific, Inc., PCRC-11 relative humidity sensor. The probe is mounted in a 12-plate naturally aspirated shield.

\section{Flow Measurement}

An orifice plate was selected as the flow measuring device for the solar system because of its economy, reliability and accuracy. An orifice plate is a round plate with an accurately machined hole. The plate is mounted concentrically between two orifice flanges. As with most flow measuring devices, the orifice plate must be located in a straight run of pipe away from fittings or bends that disturb the fluid flow. The flow restriction creates a differential pressure across the plate that is measured at pressure taps within the orifice flanges located one inch up and one inch downstream of the 
plate. Thus, the primary device is simple, has no moving parts, and if the flowing fluid is free of abrasives, will not wear out.

An orifice plate is well suited to measuring the constant rate of flow created by the centrifugal circulating pump. There are no system flow-rate controls, so the system temperature floats depending on energy collection and the load side temperatures. The characteristics of orifice plates are well documented. If the bore of the plate is specified, such that the differential pressure is near the maximum output of the measuring device, and if the fluid properties are accurately known as a function of temperature, then measurement accuracy can be better than $\pm 1 \%$. This is comparable to other flow meters, such as a turbine meter. Since about half of the measured pressure drop through the orifice is recovered downstream, the permanent pressure loss through the device is similar to a turbine meter.

The most expensive part of the flow measuring system is the differential pressure transmitter, a Rosemount model 1151 DP, used to convert the differential pressure into a 4-20 milliamp signal that can be read by the datalogger. Such transmitters are typically rugged and reliable, even in an outdoor environment. They can be calibrated in place and have an additional attractive feature of local indication of flow. Accuracy of the meter is $\pm 0.2 \%$ of the calibrated span.

\section{Circulating Fluid Temperature Measurement}

The temperatures of the fluid into and out of the solar field are measured using type E thermocouples. These are reliable and low cost devices of good accuracy within $\pm 1^{\circ} \mathrm{C}$. The thermocouples are mounted inside thermowells to allow for periodic checking against the ice point. The thermowells are filled with silicone grease to improve heat transfer between the thermocouple and the collector fluid. 


\section{Datalogger and System Integration}

The input signals are digitized and stored in a 21- $X$ datalogger from Campbell Scientific, Inc. This datalogger can accept up to 8 differential or 16 single-ended analog voltage inputs and up to 3 pulse inputs. All signal wires (except thermocouple wires) are shielded twisted pair 22-gauge stranded with UV stabilized insulation. Thermocouple type E extension wire is used to transmit thermocouple signals.

In addition to reading the input signals, the datalogger is programmed to perform calculations of sun angle, array incidence angle, specific heat and mass flow of the working fluid, and system efficiency. These calculated data along with all input data are averaged and stored every 10 minutes. A 1200 baud modem connects the datalogger to the local telephone system. The datalogger can be accessed by modem at any time without interfering with normal data collection.

The data are collected automatically each night by a dedicated collection computer at SWTDI. Daily data files are processed through a quality assurance program that verifies that all signals are within preset range limits set for each channel. Additional checks are made of the irradiance channels to confirm that the sum of the direct plus the diffuse signals is reasonably close to the measured total horizontal irradiance (correcting for the incidence angle involved). All data are archived on 2 magnetic media: 9-track recording tape and 40-megabyte cassette tape. Data plots are generated each week for review by an engineer.

An integrated set of PC software was developed for use with the DAS. This software provides a menu-driven interface that allows the user to collect stored data from the DAS, monitor DAS inputs in real-time, backup data files automatically, perform quality assurance analysis of raw data, and generate Lotus-123 plots. 


\section{System Maintenance}

\section{Routine Operations}

Routine maintenance on the solar system is carried. out by local personnel employed by IST on a part-time basis. Typically, the maintenance person makes a walk through inspection three times per week. This schedule is dictated by the responsibility to align the sun intensity instrumentation. Checks are made to ensure that the pyrheliometer is pointed to the sun, that the shadow band on the pyranometer is adjusted properly, and that the datalogger is recording all the channels. While on-site, the maintenance person checks the indicating lights on the system master controller, records the Btu and flow data from the Btu meter, and other data not recorded by the data logger such as fluid level in the expansion tank and system pressures. The site inspection includes a walk around the system to verify that all the rows are operating.

Once per week during the walk through inspection, the flexhoses are checked for any sign of fluid leakage. During this time, the local controllers are also inspected to check that the indicating lights are functioning correctly. In addition, the cover glasses on the three irradiance monitoring instruments are cleaned.

A more detailed inspection is carried out on the system once per month. The maintenance person walks along each collector row, checking the receiver supports and glazing for anything unusual. During this period, the eight drives involving the drive motor and jack-screw, wire rope, and limit switches are also inspected. Spot checks are carried out to ensure that the collectors are maintaining focus on the sun. The fence is inspected for signs of damage to the chain link or the screening, and the piping and electrical conduit are inspected for signs of leakage or breaks at the joints. Piping inside the boiler room and the mechanical seal on the pump are checked for leakage. 
The screw jack is lubricated on a bi-annual basis. The electric motors are greased annually.

\section{Reflector Cleaning}

The accumulation of dirt on the reflectors and receiver glazings has a major impact on system performance. To minimize these losses, the collectors are washed using deionized water delivered through a pressure washer. This is a noncontact cleaning procedure that does not scratch the surface of the reflective film. Washing the entire field takes 2 people 8 hours and consumes about 600 gallons of water.

During 1991, because of adverse weather, equipment problems and changes in personnel, the system was washed only three times: in April, July and September. The loss of reflectance because of soiling on the collectors has only been measured infrequently, when IST's Denver personnel have been on-site with a portable reflectometer on loan from the National Renewable Energy Laboratory (NREL). However, measurements taken in June and December provided comparable results. In both instances, the collectors had not been washed in about two months and reflectance had declined to the level of 75 to $77 \%$ of that of the pristine film. Throughout the plant's operating history, soiling losses have been exacerbated by the windy environment, the bare dirt in the collector field, and major earth moving activities that were going on for months just outside the solar field. Washing increased the reflectance to about $92 \%$ of the pristine value. This is a considerable increase, but illustrates the permanent loss of reflectance resulting from a persistent layer of dirt that adheres to the film and is not removed by pressure washing. 


\section{Wind Related Maintenance Actions}

Tehachapi is a very windy location and is the site for thousands of wind turbines. Winds are particularly strong during the winter months when the Santa Anna's blow in from the east-practically head-on to the collectors. For the solar thermal system, the wind forces generated on the collector array are reduced through the use of a screened perimeter fence.

The data acquisition system came on line in February. During March, a maximum peak wind speed of $75 \mathrm{mph}(121 \mathrm{kph})$ was measured by the anemometer located $16 \mathrm{ft}(4.8 \mathrm{~m})$ above the ground and about $6 \mathrm{ft}(1.8 \mathrm{~m})$ above the top of the wind fence. This is equivalent to a wind speed in excess of $80 \mathrm{mph}(129 \mathrm{kph})$ at the standard measurement height of $33 \mathrm{ft}(10 \mathrm{~m})$ generally used in open terrain.

Strong and constant winds create a punishing environment for the collectors, imparting prolonged and cyclic stress on all system components. During almost every month of the year, the solar system was shut down at some time during daylight hours as a result of high winds. When the solar system is operating, high winds during the daylight hours reduce system performance by increasing convective heat loss from the receiver tube and piping and by contributing to tracking errors as the collectors flex in the wind.

Wind, in combination with heavy snow, contributed to lack of performance in March. Wind and snow loads on the collectors in stow caused some misalignment of the modules, and manual realignment was required to correct this problem. In addition, the system was shut down for several days to allow the snow drifts that had formed under the collectors to melt. 


\section{Controls Related Maintenance Actions}

The winter environment revealed flaws in new system components. In March, the switch that closes to indicate flow (needed before sun tracking can begin) failed, thus keeping the system in stow for several days. The switch was replaced.

Also in March, perhaps as a result of high humidity and unusual soil chemistry, the gold leads on the collector tracking sensors exhibited corrosion resulting in erratic tracking of the collectors. The corroded sensors were replaced with a weather proof version.

In August, the 24-volt power supply to the master controller failed. This disabled the field for 5 days until temporary batteries were installed. Problems with these batteries further interrupted performance, until they were replaced with a more suitable variety and a battery charger.

\section{System Interface Related Maintenance Actions}

In July, the pressurized water circulating pump that delivers heat to the entire complex shut down. This was not detected in the boiler room for over an hour until the safety valve on the water side of the main solar-system heat exchanger lifted. The solar system had overheated due to lack of cooling. The overtemperature switch had operated in a cyclical fashion allowing the build up of temperature. A recurrence has been prevented by adding a switch to the overtemperature controller that requires a manual reset to restart the solar system after a similar event.

During November, the solar system was shut down for most of one day for required maintenance in the boiler room.

\section{Replacement Of The Flexible Hoses}

The flexible hoses that connect the moving absorber tube and fixed piping system are the weak link in the piping of parabolic trough systems. To extend the life of these 
hoses, IST originally used a conservative hose design. However, this design turned out to be overly conservative. The hoses restricted the angular rotation of the collectors and caused the system to shut down early in the afternoon each day.

To overcome this problem and to develop a hose design capable of many years of operation without failure, IST and the STDAC at SNL cooperated on a design, development, and testing program. The effort was successful, and new hoses were installed during late November and early December. Retrofit of the hoses required that the system be shut down for several days during this period.

\section{System Electrical Load}

The circulating pump is the major system user of electricity. The eight collector drives operate only for a short time period each day and draw little power. Standby loads include the power to operate the local controllers, the battery charger (as required), the data acquisition system and the step down transformer. When the system is operating, the average electrical load is $4.3 \mathrm{~kW}$. Nonoperating standby loads measure $180 \mathrm{~W}$. 


\section{Performance Data}

Performance and resource assessment data have been monitored at the Tehachapi site since mid-February 1991. This report presents data recorded from March 1, 1991 through December 31, 1991. With the exception of four days in July, the DAS operated every day during this reporting period. Initially, the plant was in its shakedown or startup period, during which operational problems related to startup were identified. System availability improved throughout the first few months of operation and the shakedown period was considered over by June 30, 1991.

\section{Plant Availability}

Figure 5-1 shows the recorded monthly plant availability for 1991. As mentioned earlier, the collectors track the sun in one axis. The constraints of interrow shading and mechanical limits imposed on the collectors' travel by the flexible hoses mean that the collectors do not operate from sunrise to sunset. Availability has been calculated only for the hours during which the sun was in the region of the sky on which the collectors could be focused. In this way, no penalty is imposed for nonproducing hours when the sun is low on either horizon; thus plant unavailability reflects periods of downtime, planned maintenance or, frequently, stow positions as a result of high winds or snow. In the post-startup period, the months with plant availability below $90 \%$ were: August, because of a failure of the power supply for the field master controller; November, because of several days of sustained high winds and the planned downtime required by the replacement of the collector's flex-hoses; and December, because of many days of sustained high winds and the continuation of the flex-hose replacement program. 


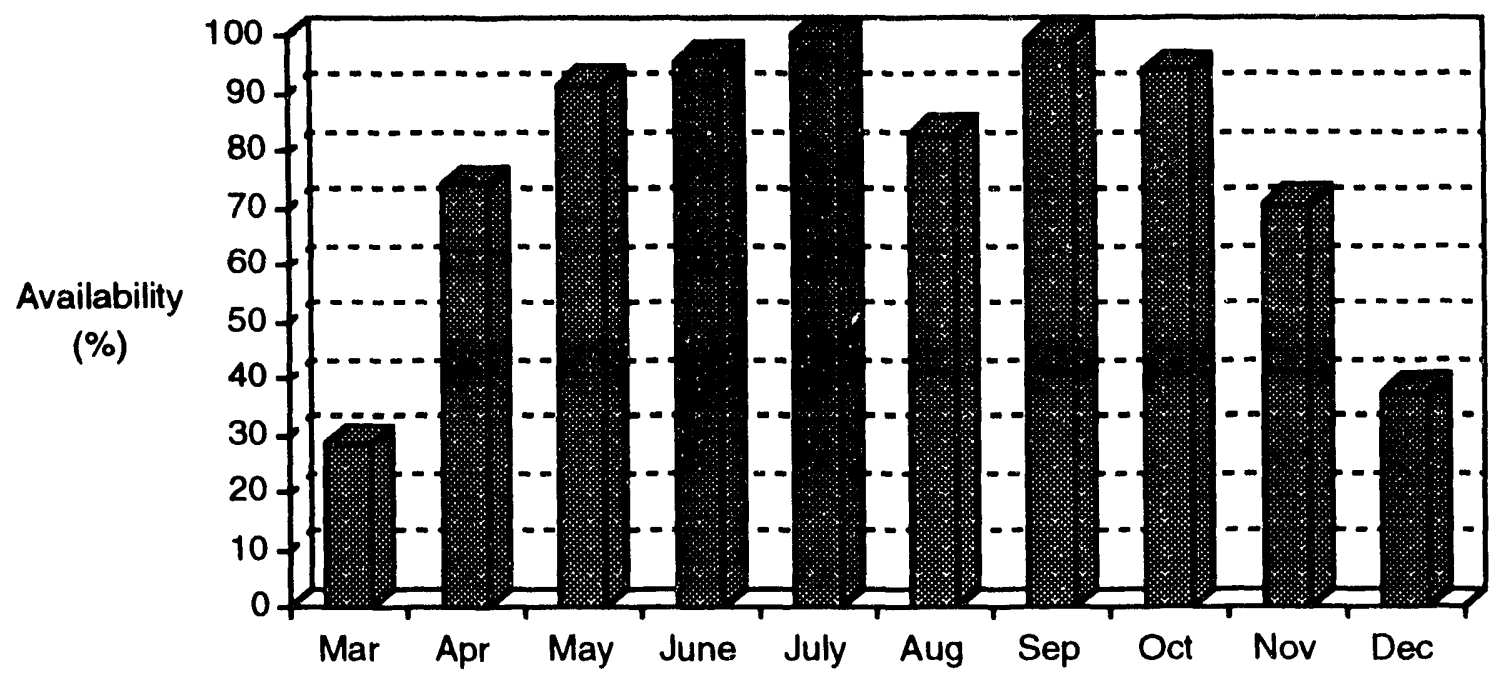

Figure 5-1. Monthly plant availability

\section{Plant Energy Production}

Figure 5-2 shows the monthly plant energy production and plane of array insolation. Plane of array insolation is the direct normal insolation in the aperature plane of the collectors (see Appendix A for the defining equations). As mentioned earlier, energy and insolation data were not recorded during four days in July because of a failed battery. It is estimated that if these data had been available, the month of July would have recorded the highest monthly plant production and insolation levels: approximately $800 \mathrm{MMBtu}$ of thermal energy delivery under insolation of $2432 \mathrm{MMBtu}$.

June produced the plant's highest hour of peak energy delivery, 4.1 MMBtu. Peak energy hours of slightly more than 4.0 MMBtu were recorded during July and August. In the 10 month period from March through December 1991, the plant delivered a total of 3,674 MMBtu of energy (including an estimated $103 \mathrm{MMBtu}$ produced during the four days during which no data were recorded). Based on a boiler efficiency of $65 \%$ to $75 \%$, the energy produced by the solar plant during this 10 month period displace from 49,000 to 57,000 therms of natural gas. 


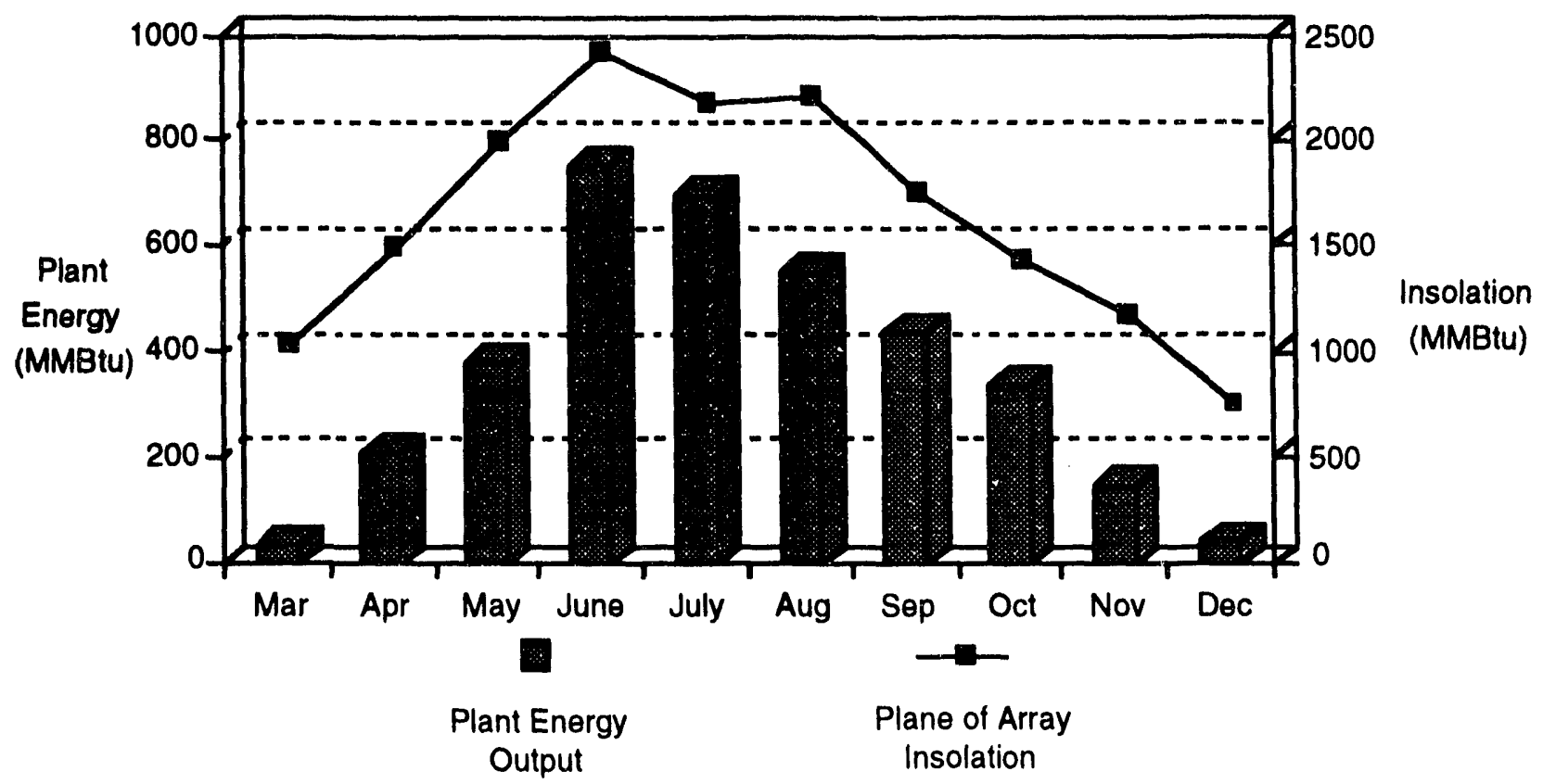

Figure 5-2. Monthly plant energy production and plane of array insolation

Figure 5-3 shows the overall plant conversion efficiency recorded for each of the 10 months in the reporting period. Monthly efficiency figures have been calculated only for periods when the plant was either fully or partially operating. Daylight hours when the plant was completely shut down or in wind stow have been excluded.

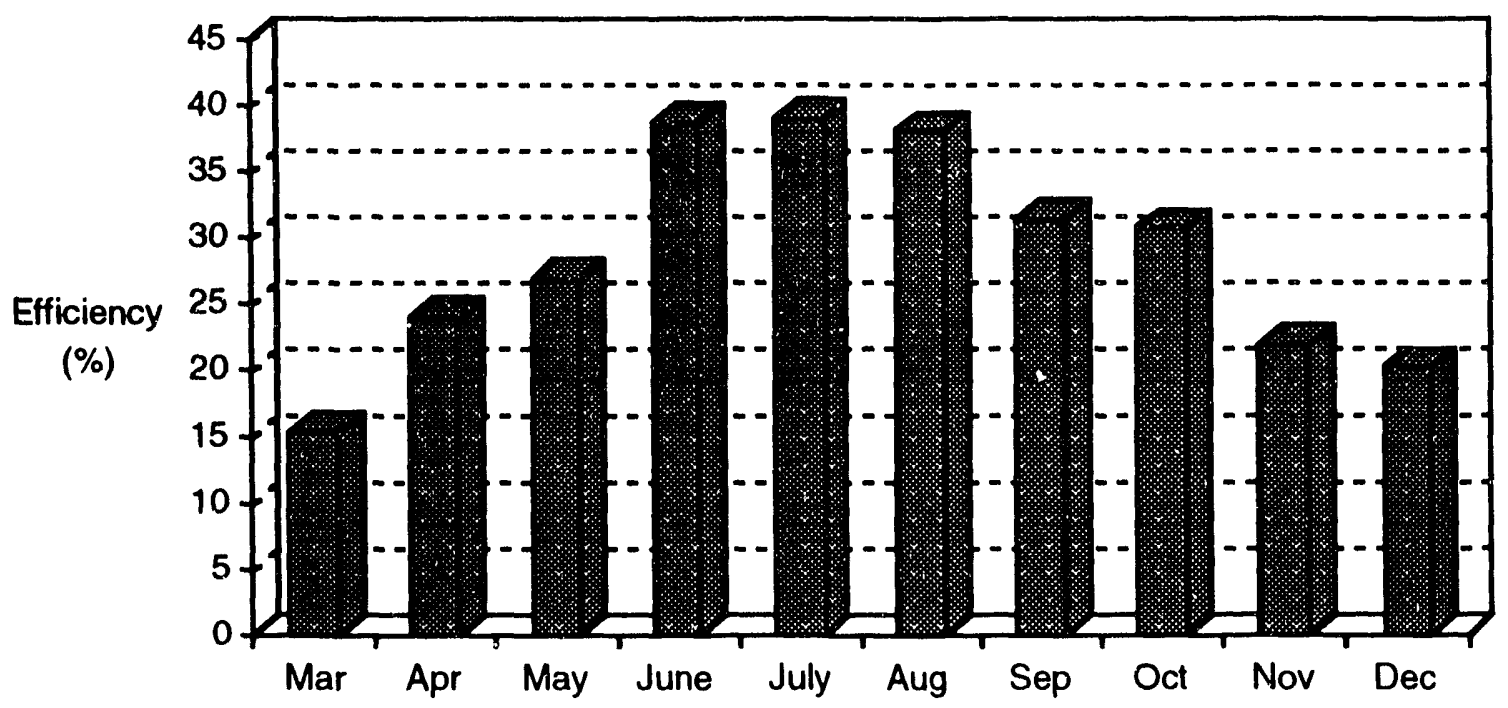

Figure 5-3. Monthly plant conversion efficiency 
Based on operating hours only, the highest monthly efficiency was $40.0 \%$, recorded in July. Considering only post-startup months, the lowest recorded monthly efficiency was in December, $20.2 \%$. Low efficiency during the months of November and December reflect the higher solar incidence angles encountered during these winter months and 3 weeks of operation with parts of the plant shut down for replacement of the collectors' flex hoses.

\section{Plant Performance Versus Irradiance Range}

Figure 5-4 presents the plant energy production and operating time recorded in various plane of array irradiance ranges. Figure 5-5 shows the plant conversion efficiency recorded for the various plane of array irradiance ranges. Plant conversion efficiency increases with irradiance. The highest efficiency was recorded for the 300-350 $\mathrm{Btu} / \mathrm{hr}-\mathrm{ft}^{2}$ range, $39.2 \%$. Only $3.4 \%$ of the plant's operating time was spent with irradiance above $300 \mathrm{Btu} / \mathrm{hr}-\mathrm{ft}^{2}\left(946 \mathrm{~W} / \mathrm{m}^{2}\right)$.

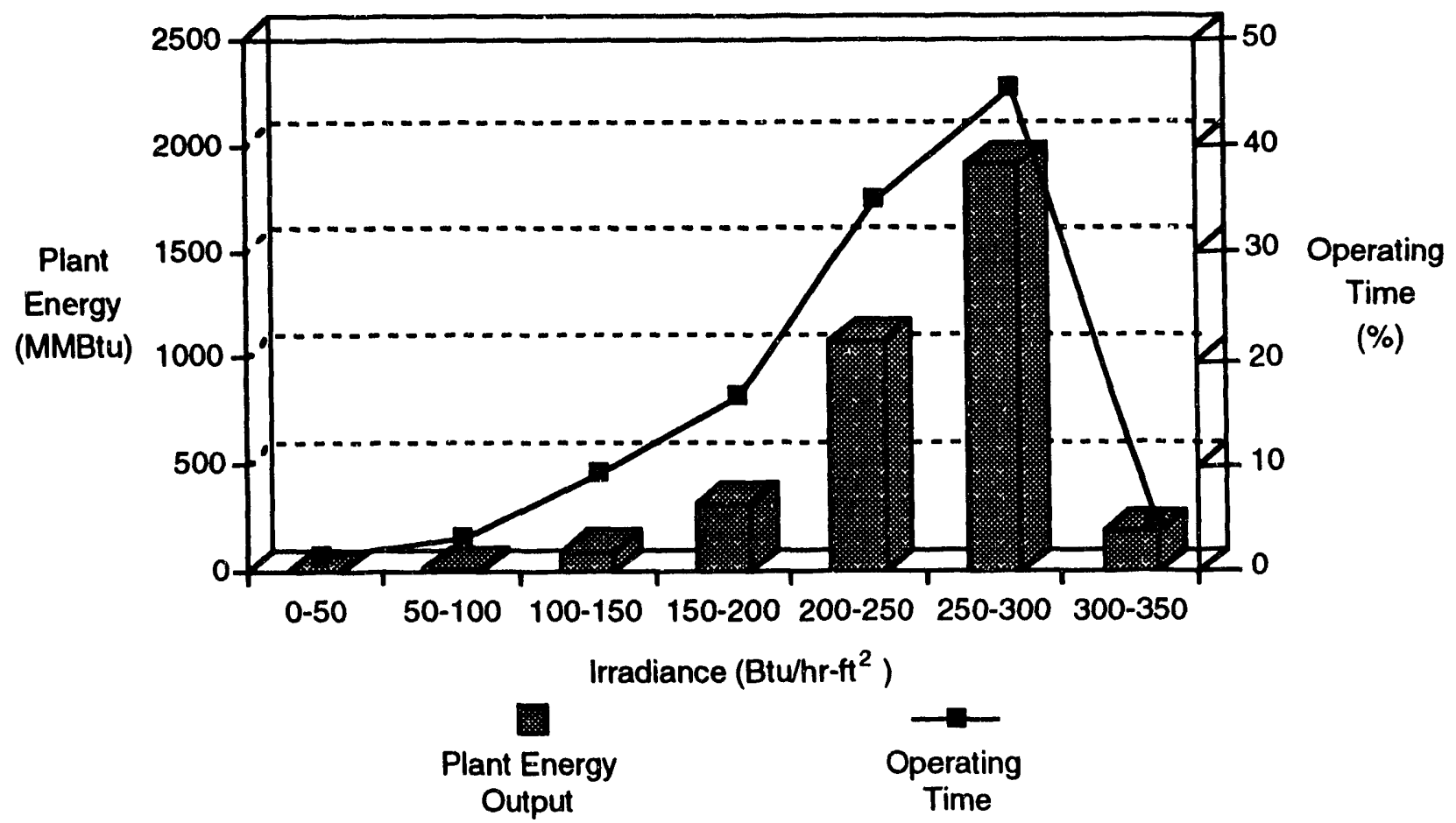

Figure 5-4. Plant energy output and operating time versus irradiance range 


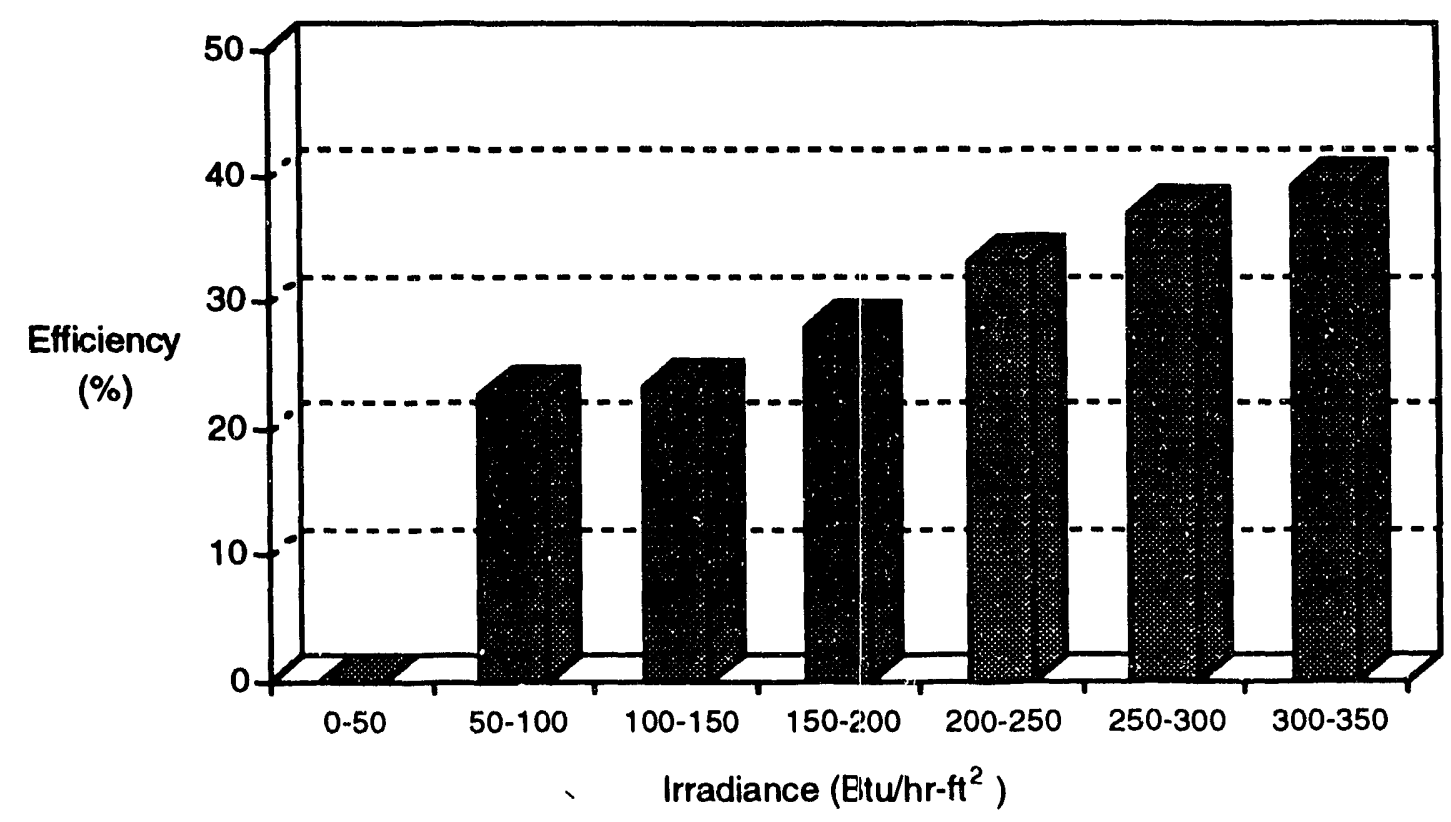

Figure 5-5. Plant conversion efficiency versus irradiance range

\section{Clear Day Performance}

Figures 5-6 and 5-7 present plant performance data for July 14, 1991. Figure 5-6 shows the flow rate of the circulating fluid and its measured temperature at the inlet and outlet of the solar array field. On this day, the circulating pump came on at 6:10 am and the array was producing energy from 6:30 am until 4:00 pm. Figure 5-7 shows the insolation available in the solar collector plane, the plant's energy production, and the associated conversion efficiency of the plant. The maximum hourly conversion efficiency of $43.5 \%$ was achieved in the period from 1:00-2:00 pm, During this hour, the plant circulated a constant flow through the collector field of $154.5 \mathrm{gal} / \mathrm{min}(584.8$ $1 / \mathrm{min}$ ) with an average temperature rise of $5.2 .3^{\circ} \mathrm{F}\left(11.2^{\circ} \mathrm{C}\right)$, producing $3.82 \mathrm{MMBtu}$ of energy. Peak collector outlet temperature reached $267^{\circ} \mathrm{F}\left(130.6^{\circ} \mathrm{C}\right)$. Overall, during this day's 9.5 hours of operation, the plant produced 30.9 MMBtu of energy with an average conversion efficiency of $38.8 \%$. 


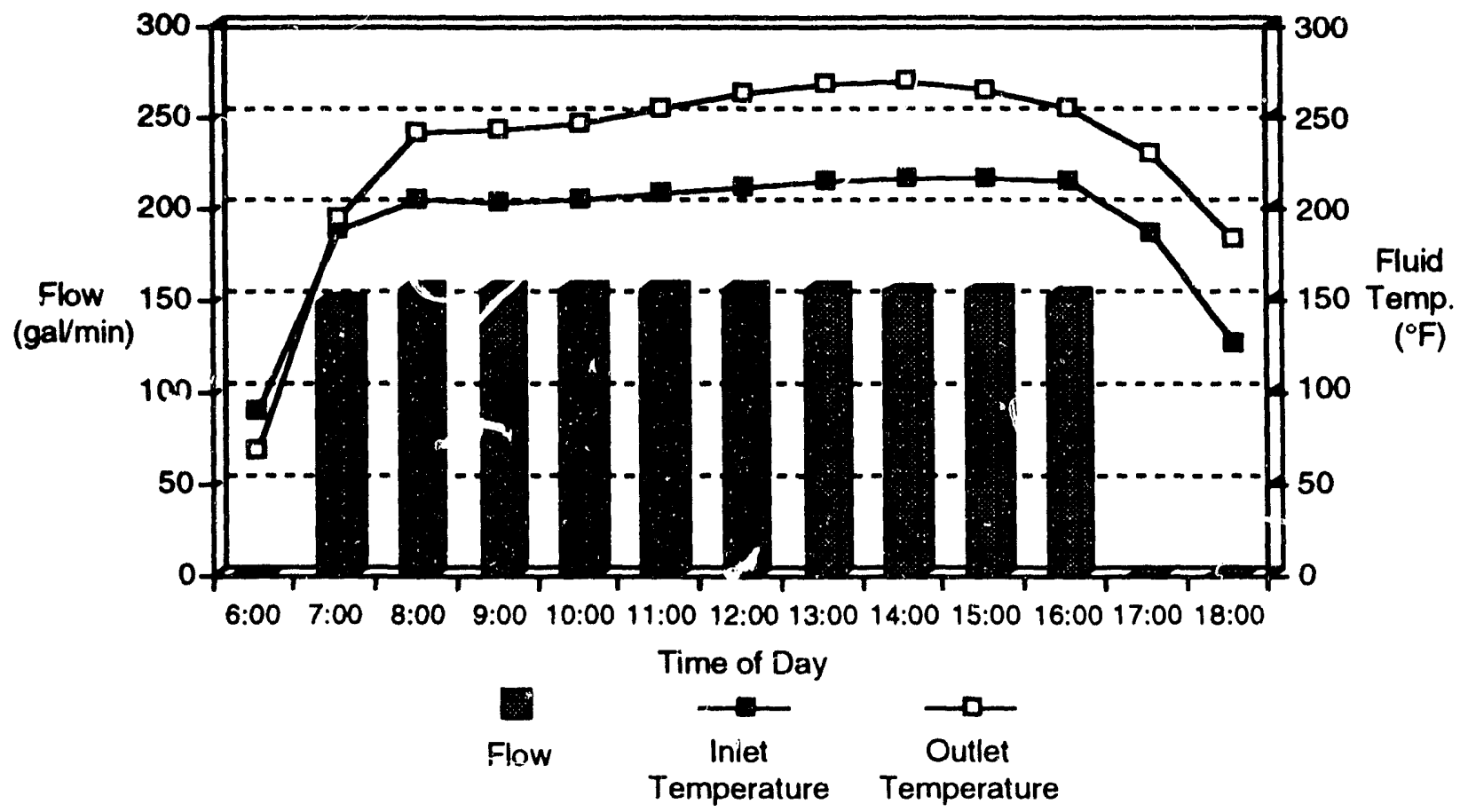

Figure 5-6. Collector temperatures and flow rate for July 14, 1991

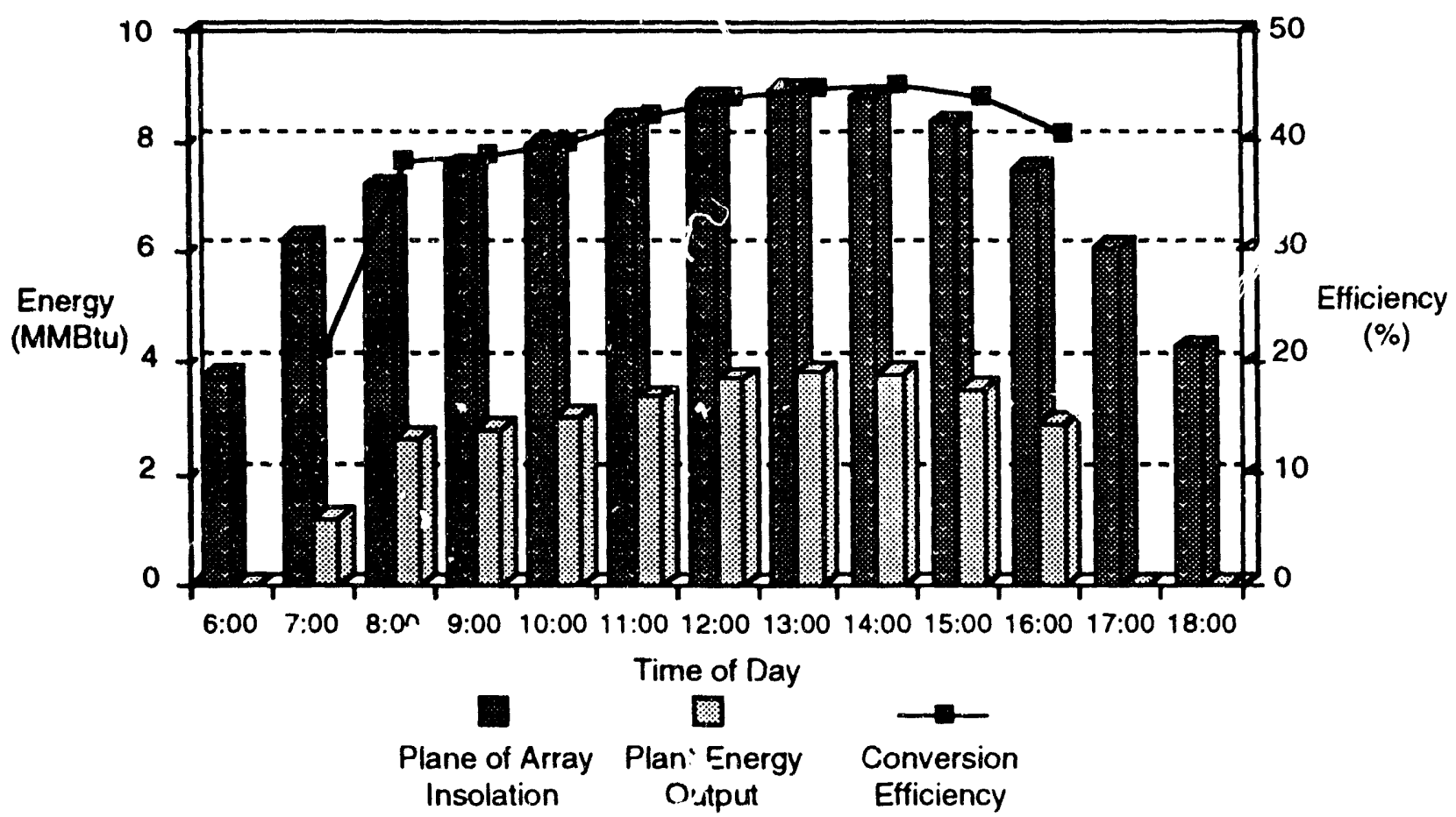

Figure 5-7. Insolation, energy output, and efficiency for July 14, 1991 
Figures 5-8 and 5-9 present plant performance data for November 5, 1991. Figure 5-8 shows the flow rate of the circulating fluid and its measured temperature at the inlet and outiet of the solar array field. In the figure, the data for the 8:00 hour show a warmer inlet than outlet temperature. This entry represents the average of all temperature readings taken from 7:00 until 8:00. Thus, although the circulating pump came on at 7:20 am and the system was producing energy after about 30 minutes, the 8:00 entry indicates that the average inlet temperature was warmer than the average outlet temperature. In fact, the plant produced energy from 7:50 am until 2:40 pm.

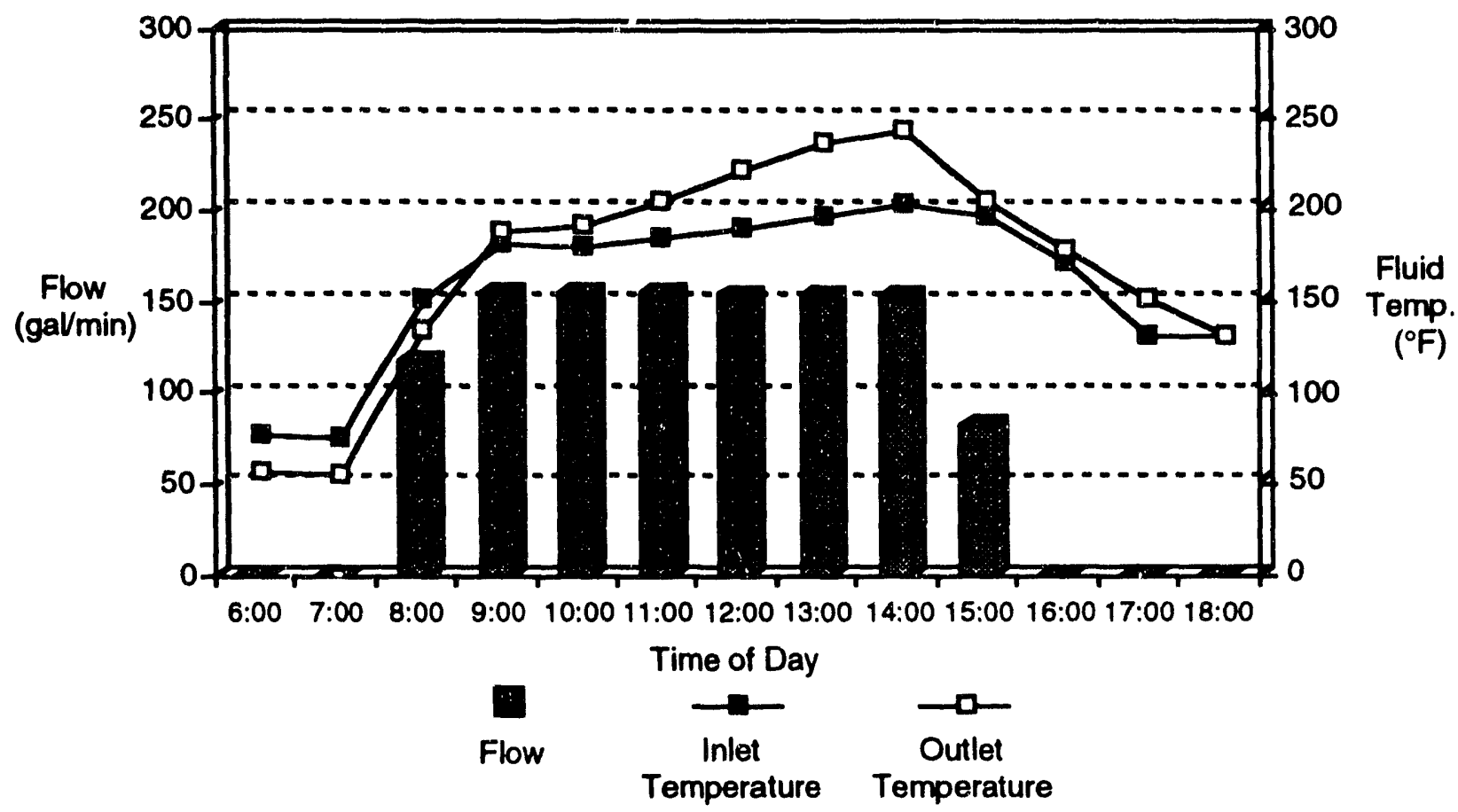

Figure 5-8. Collector temperatures and flow for November 5, 1991 
Figure 5-9 shows the insolation available in the solar collector plane, the plant's energy production, and the associated conversion efficiency of the plant. The maximum hourly conversion efficiency of $39.4 \%$ was achieved in the period from 12:00-1:00 pm. During this hour, the plant circulated a constant flow through the collector field of 154.0 $\mathrm{gal} / \mathrm{min}$ with an average temperature rise of $39.7^{\circ} \mathrm{F}\left(4.2^{\circ} \mathrm{C}\right)$, producing $2.87 \mathrm{MMBtu}$ of energy. Overall, during this day's 6 hours and 50 minutes of operation, the plant produced 11.5 MMBtu of energy with an average conversion efficiency of $21.9 \%$.

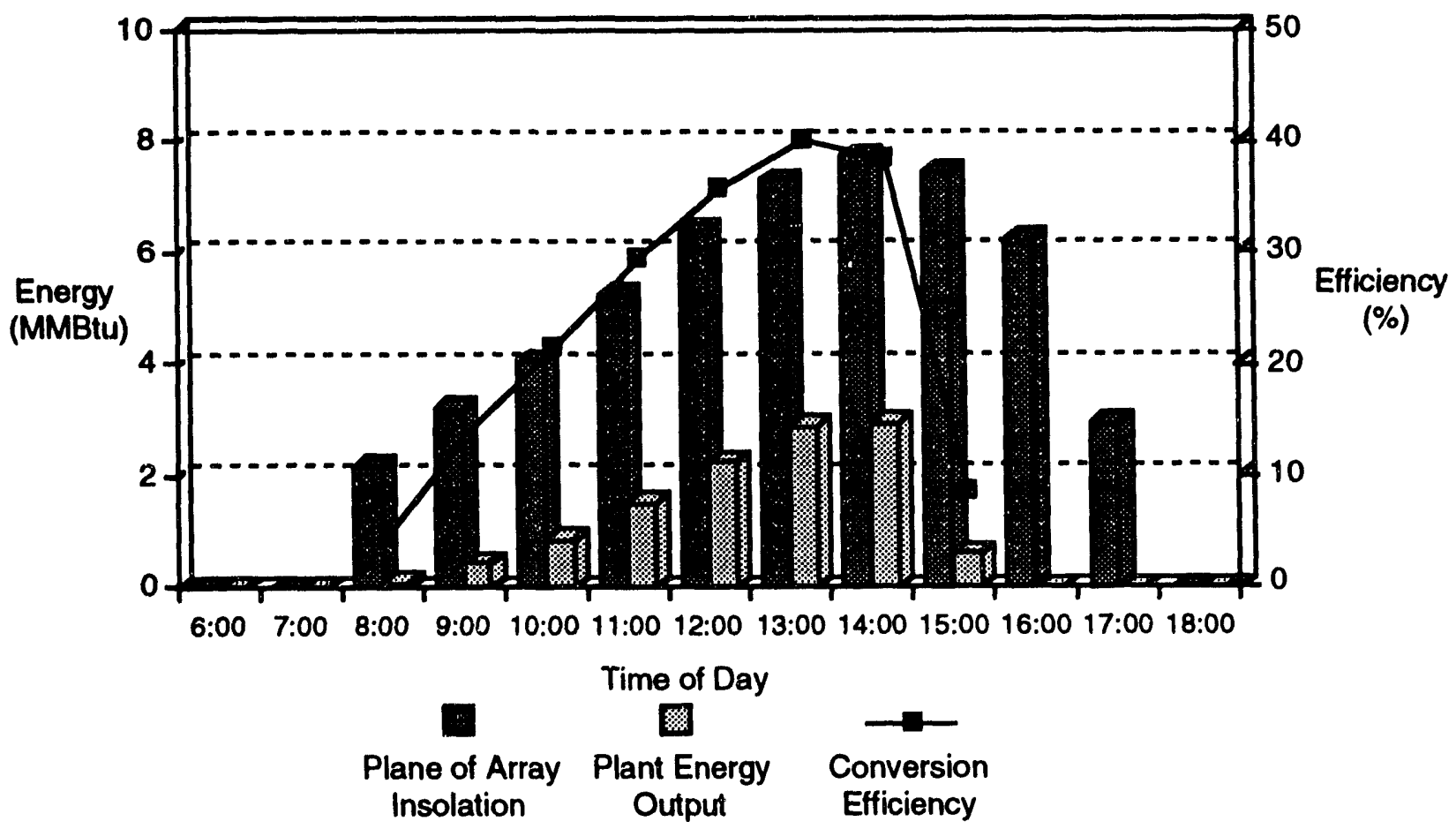

Figure 5-9. Insolation, energy output, and efficiency for November 5, 1991 


\section{Solar Resource and Wind Data}

The data acquisition system was installed to provide solar resource and wind monitoring for the Tehachapi site as well as performance monitoring of the solar thermal plant. This section presents data that characterize the ambient conditions present at the site during the reporting period from March through December 1991.

\section{Wind Data}

Figure 6-1 presents the average and maximum wind speeds recorded during each month. The site of the Tehachapi system is extremely windy, experiencing sustained high winds in the winter and spring months. The system master controller is designed to place the collectors in wind stow position when peak winds exceed approximately $20 \mathrm{mph}(32.2 \mathrm{kph})$.

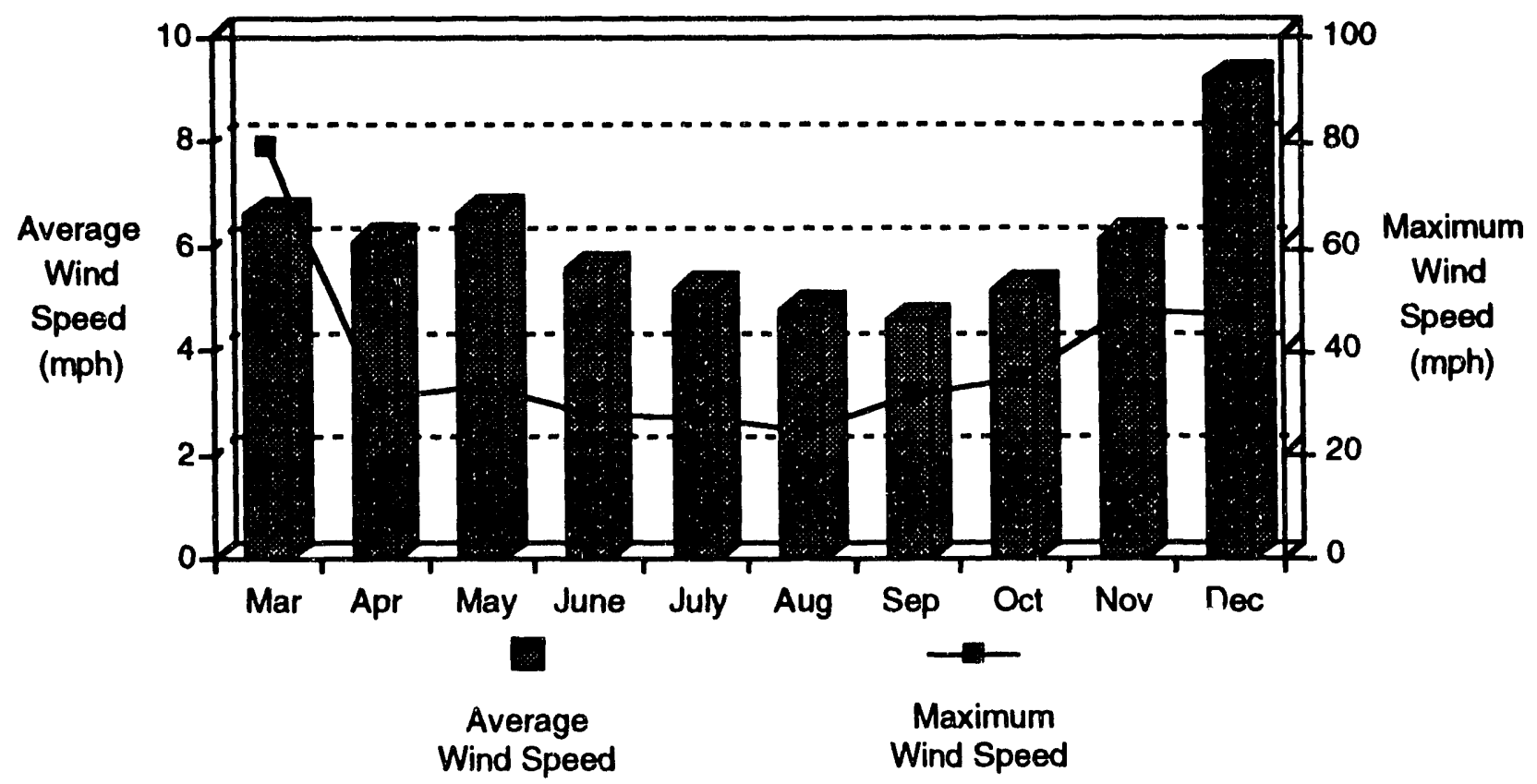

Figure 6-1. Monthly average and maximum wind speeds 


\section{Ambient Temperature and Relative Humidity Data}

Figure 6-2 presents the average ambient temperature and relative humidity recorded during each month. Relative humidity is highest during the winter and spring months.

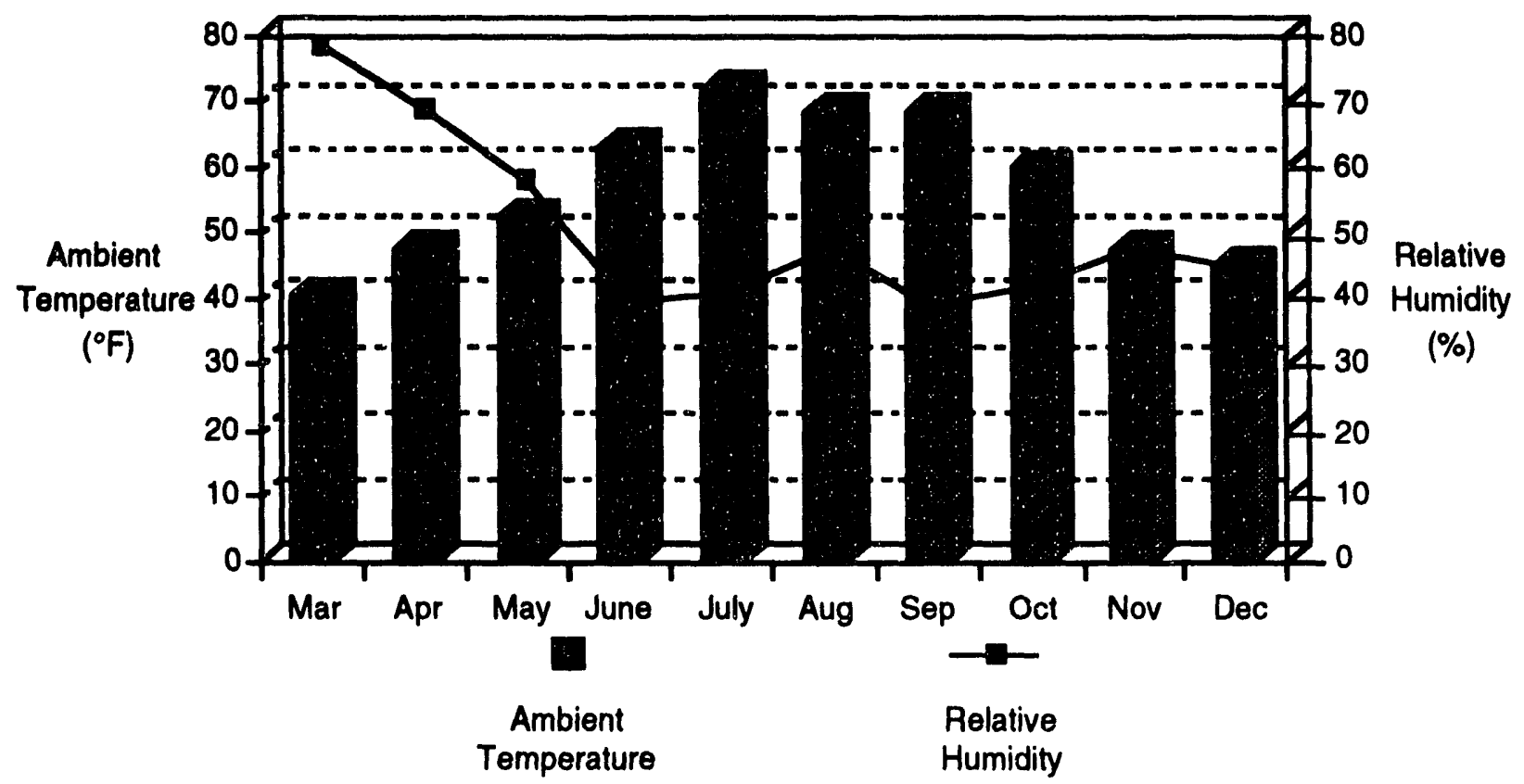

Figure 6-2. Monthly average ambient temperature and relative humidity

\section{Insolation Data}

The DAS is instrumented to measure direct normal, global horizontal, and diffuse irradiance. In addition, the datalogger is programmed to perform the calculations necessary to determine the irradiance present in the plane of collector array. Figure 6-3 presents these insolation totals recorded for each month of the reporting period. There are two known anomalies present in the figure. The data for July are low, due to failure of the datalogger for four days. And improper alignment of the shadow band in October resulted in erroneously high diffuse insolation readings. 


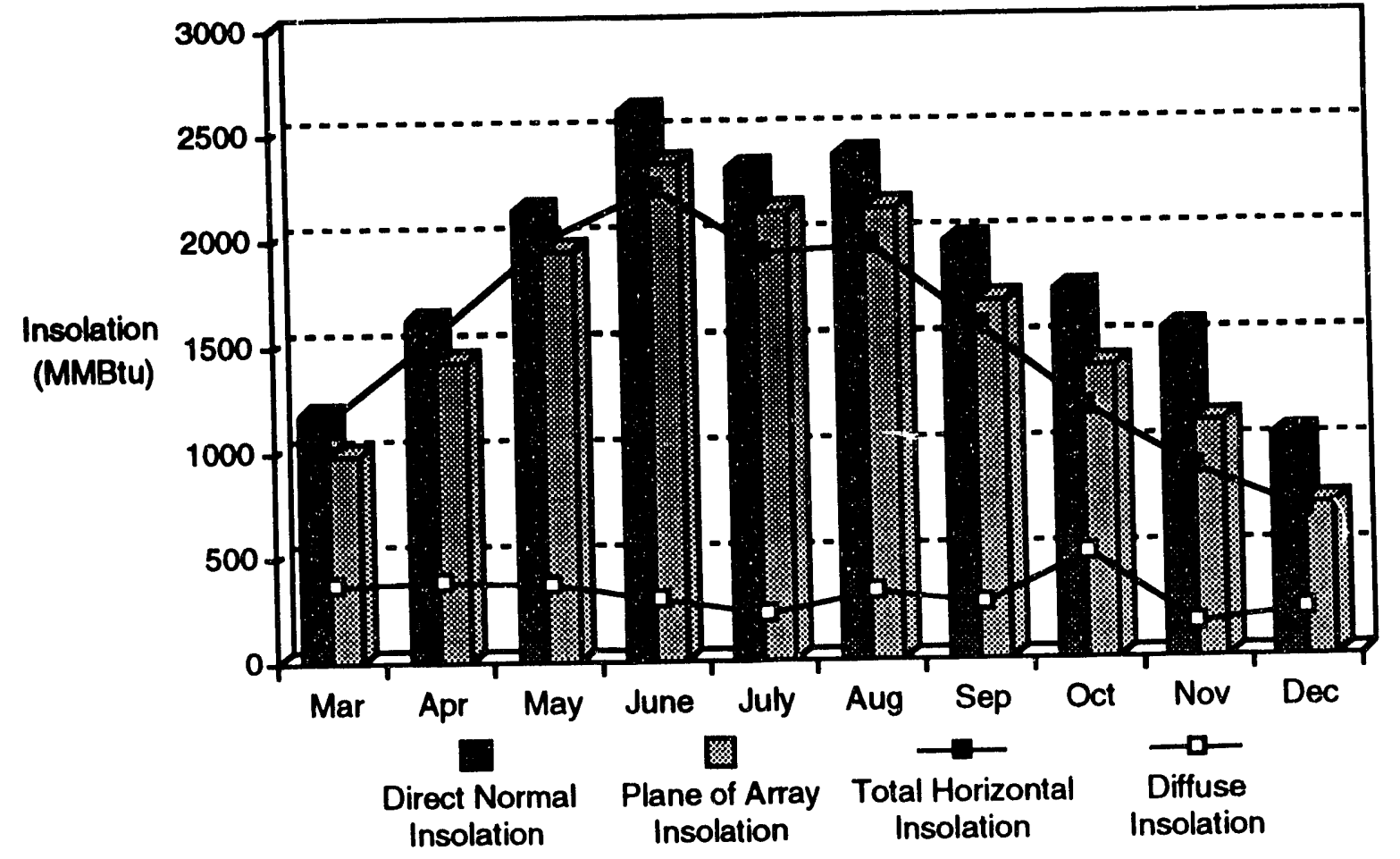

Figure 6-3. Monthly totals for direct normal, plane of array, total horizontal, and diffuse irradiance 
Appendix A. Definitions and Equations 


$$
\text { A-2 }
$$


Appendix A. Definitions And Equations

Density

Specific Heat

Orifice Exp. Coeff.

Head of Water

Flow

Power

Equation of Time

Solar Time

Hour Angle

Declination

Sine of solar

elevaton angle

Cosine of solar elevation angle

Sine of solar azimuth angle

Cosine of solar azimuth angle

Cosine of the solar incidence angle

Efficiency

$$
\rho\left(\mathrm{lb} / \mathrm{ft}^{3}\right)=66.19-0.01161 \mathrm{~T}_{\mathrm{i}}-0.000030409 \mathrm{~T}_{\mathrm{i}}^{2}
$$$$
\mathrm{C}_{\mathrm{p}}\left(\mathrm{Btu}_{\mathrm{u}} / \mathrm{lb}^{\circ} \mathrm{F}\right)=0.866+0.000346\left(\mathrm{~T}_{\mathrm{i}}+\mathrm{T}_{\mathrm{o}}\right) / 2
$$

$F_{a}$

$$
=1+0.000021\left(\mathrm{~T}_{\mathrm{i}}-68\right)
$$

$h_{W}$ (inches) $\quad=(m A-4) 150 / 16$

$M(l b / h r) \quad=1277.4 \mathrm{Fa}_{\mathrm{a}}\left(\mathrm{h}_{\mathrm{W}} \rho\right)^{1 / 2}$

$\mathrm{P}(\mathrm{Btu} / \mathrm{hr}) \quad=\mathrm{MC} \mathrm{C}_{\mathrm{p}}\left(\mathrm{T}_{\mathrm{o}}-\mathrm{T}_{\mathrm{i}}\right)$

EOT (minutes) $=[9.87 \sin (2 \mathrm{~B})-7.53 \cos (\mathrm{B})-1.5 \sin (\mathrm{B})]$ where: $\quad B=360$ (Julian Day - 81) $/ 364$

Solar Time = standard time $+4\left(\mathrm{~L}_{\mathrm{st}}-\mathrm{Lloc}\right)+$ EOT where: $\quad \mathrm{L}_{\mathrm{st}}=120^{\circ}$ and $\mathrm{L}_{\mathrm{loc}}=118.5^{\circ}$

$\omega$ (degrees) $=[($ Solar Time $/ 60)-12] * 15$

$\delta$ (degrees) $=23.45 \sin [360 *(284+$ Julian Day $) / 365]$

$\sin (\mathrm{ELs})$

$$
=\sin (\mathrm{L}) \sin (\delta)+\cos (\mathrm{L}) \cos (\delta) \cos (\omega)
$$

where: $\quad \mathrm{L}=$ site latitude $\left(35.12^{\circ}\right)$

$$
\cos (\mathrm{ELs}) \quad=\left[1-\sin ^{2}(\mathrm{ELs})\right]^{1 / 2}
$$

$\sin (\mathrm{AZs})$

$=\cos (\delta) \sin (\omega) / \cos (\mathrm{ELS})$

$\cos (\mathrm{AZs})$

$$
=[\sin (\mathrm{L}) \cos (\delta) \cos (\omega)-\cos (\mathrm{L}) \sin (\delta)]
$$
$\cos$ (ELs)

$\cos (\theta)$ $=\left[1-\cos ^{2}(\mathrm{ELs}) \cos ^{2}(\mathrm{AZc}-\mathrm{AZs})\right]^{1 / 2}$

$\eta$

$=($ Power *100) $/[28,800 *$ NIP * $\cos (\theta)]$ 


\author{
1606 Civil Engineering Squadron \\ Attn: James Fejer \\ 1606 ABW/DEM \\ Deputy Chief, Operations Branch \\ Kirtland AFB, NM 87117-5496 \\ 3M-Energy Control Products (2) \\ Attn: R. Dahlen \\ P. Jaster \\ 207-1W 3M Center \\ St. Paul, MN 55144

\section{M-Solar Optics Program} \\ Attn: Paul Jaster \\ 3M Center \\ Heather Kutzler \\ Bldg. 225-2n-06 \\ St. Paul, MN 55144-1000 \\ Advanced Thermal Systems \\ Attn: Dave Gorman \\ 7600 East Arapahoe Rd., Suite 215 \\ Englewood, CO 80112 \\ Alabama Power Co. \\ Attn: Greg Reardon \\ P.O. Box 2641
}

Birmingham, AL 35291

Alabama Solar Energy Center

Attn: Leonard Adcock

University of Alabama in Huntsville

Huntsville, AL 35899

Alan Richardson

Business Liaison

New Postal Building

Room 3004

Santa Fe, NM 87501

American Institute of Architects

Attn: Richard C. Depta, AIA

Director Energy Information

1735 New York Ave., NW

Washington, DC 20006

Applied Concepts

Attn: S. Pond

2501 S. Larimer County Rd. 21

Berthound, CO 80513

Applied Research Associates, Inc. 4300 San Mateo NE, Suite A-220

Albuquerque, NM 87110
Aqua Vit Foundation

Attn: Rob Sangster

324 Wilkinson

Memphis, TN 38111

Argonne National Laboratory

Materials and Components Technology Div

Attn: Robert E. Holtz

9700 South Cass Avenue

Argonne, IL 60439

Arizona Department of Commerce

Arizona Energy Office

Attn: Jack Haenichen Frank P. Mancini, Ph.D.

3800 N. Central, Suite 1200

Phoenix, AZ 85012

Arizona Public Service Co.

Attn: Thomas C. Lepley

J. McGuirk

P.O. Box 53999

Phoenix, AZ 85072-3999

Ascension Technology

Attn: Ed Kem

Box 314

Lincoln Center, MA 01773

AT\&T

Attn: Gregory P. Robertson, P.E.

P. O. Box 13369

Phoenix, AZ 85002

Augustyn \& Company

Attn: Jim Augustyn

1029 Solano Ave., Suite C

Albany, CA 94706

B\&E Technical Services Inc.

Attn: William R. Lang

600 S. Cherry St. \#325

Denver, CO 80222-1705

Barber-Nichols Engineering

Attn: R. Barber

6325 West 55th Ave.

Arvada, CO 80002

Battelle Pacific Northwest Laboratory (2)

Attn: D. Brown

P.O. Box 999

Richland, WA 99352 
BDM Corporation

Attn: Tim Lanbarski

MS-C35B

W. E. Schwinkendorf

1801 Randolph Street, S.E.

Albuquerque, NM 87106

Bechtel National, Inc. (3)

Attn: P. DeLaquil

S. Nickovich

W. Stolte

50 Beale Street

50/15 D8

P.O. Box 3965

San Francisco, CA 94106

Black \& Veatch Consulting Engineers

Attn: J. C. Grosskreutz

P.O. Box 8405

Kansas City, MO 64114

Boston Edison Company

Attn: Michael Mulcahy

800 Boylston Street

Boston, MA 02199

Brookhaven National Labs

Attn: John Andrews

National Center for Analysis

of Energy Systems

Upton, NY 11973

Budd Company (The)

Attn: John M. Vergoz

3155 W. Big Beaver Road

Troy, MI 48084

Cal Tech

Attn: R. Middlebrook

116-81 Cal Tech

Pasadena, CA 91125

California Institute of Technology

Aeronautics Library

Attn: Jean Anderson

MS 205-45

Pasadena, CA 91125

California Polytechnic State University

Attn: Dr. Safwat M.A. Moustafa, P.E.

San Luis Obispo, CA 93407
Califomia Polytochnic Univeraity

Dept. of Mechanical Engineering

Attn: W. B. Stine

Pomona, CA $91768-4062$

Carlo LaPorta

2201 Wisconsin Avenue NE

Washington, DC 20007

Carolina Power \& Light Co.

Attn: Kent Hofiman

Center Plaza Bldg.

P.O. Box 1551

Raleigh, NC 27602

City of Albuquerque

Attn: Linda Stewart

City Council

P. O. Box 1293

Albuqueque, NM 87103

City of Albuquerque

Attn: Mike Mintum, Manager

Resource Managment Division

General Services Department

P. O. Box 1293

Albuquerque, NM 87013

City of Austin Power \& Light

Attn: David Panico

P.O. Box 1088

Austin, TX 78767

City of Las Cruces

Attn: Jerry Trojan

Assist. City Manager

P. O. Drawer CLC

Las Cnuces, NM 88004

Clarkson University

Attn: Eric F. Thacher

Dept. of Mechanical and Aeronatucial Engrg.

Potsdam, NY 13699-5725

Colorado State University

Attn: Dr. Allan T. Kirkpatrick

Department of Mechanical Engineering

Ft. Collins, CO 80523

Colorado State University

Attn: Mark Thombloom

Solar Energy Applications Lab

Fort Collins, CO 80523 
Commonwealth of Virginia

Department of Mines, Minerals, Energy

Attn: Susie Thomas

The Bookbinder Building

2201 West Broad St.

Richmond, VA 23220

County of Hawaii

Attn: Steve Burns

Dept. of Research and Development

25 Aupuni Street

Hilo, HI 96720

Cummins Engine Company

Attn: Dr. Isoroku Kubo

Mail Code 50179

Box 3005

Columbus, IN 47202-3005

Cummins Power Generation South

Attn: M. McGlaun

150 Tannehill Drive

Abilene, TX 79602

Cygnus Engineering

Attn: Vincent P. Dowd

R. D. 3, Box 2527

Middlebury, VT 05753

D\&T Solar

Attn: Thomas Caldwell

418 Vista Larga

Los Lunas, NM 87031

Dan Ka Products, Inc.

Attn: D. Sallis

3905 South Mariposa

Englewood, CO 80110

Datron Systems, Inc.

200 West Los Angeles Ave.

Simi Valley, CA 93065-1650

Dayton Power \& Light Comany

Attn: S. K. Aventsen

P. O. Box 1237

Courthouse Plaza

Dayton, OH 45\&?1

Dominion Energy Corp.

Attn: John Frank

P. O. Box 26532

Richmond, VA 23261
Don Beremand

30101 Wolf Rd.

Bay Village, OH 44140

Dayton Power \& Light Company

Attn: S. K. Aventsen

P.O. Box 1247

Courthouse Plaza

Dayton, $\mathrm{OH} 45401$

Dominion Energy Corp.

Attn: John Frank

P.O. Box 26532

Richmond, VA 23261

Don Beremand

30101 Wolf Rd

Bay Village, OH $\mathbf{4 4 1 4 0}$

Donnelly Corporation

Attn: M. DeVries

49 West Third Street

Holland, MI 49423

DSET

Attn: G. A. Zerlaut

Box 1850

Black Canyon Stage I

Phoenix, AZ 85029

\section{ECOTOPE}

Energy Efficient Solutions

Attn: David R. Baylon

2812 E. Madison

Seattle, WA 98112

Electric Power Research Inst.

Attn: E. DeMeo

J. Bigger

3412 Hillview Avenue

Palo Alto, CA 94303

Endecon

Attn: Chuck Whittaker

3401 Crown Canyon Road

Suite 253

San Ramon, CA 94583

Energy Concepts Co.

Attn: Don Erickson

627 Ridgely Ave.

Annapolis, MD 21401 
Energy System Consultants

Attn: Dana Sears

1532 79th Avenue NE

Brookland Park, MN 55444

Energy Technology Engr. Ctr.

Rockwell International Corp.

Attn W. L. Bigelow

P.O. Box 1449

Canoga Park, CA 91304

ENTECH, Inc.

Attn: M. O'Neill

R. Walters

P.O. Box 612246

DFW Airport, TX 75261

Environmental Laboratory

Attn: John A. Dufay

915 Locust St., NE

Albuquerque, NM 87106-4300

ESELCO

Attn: Sheldon L. Levy

8116 Fontana

Prairie Village, KS 66208

Eurodrive, Inc.

30599 San Antonio Rd.

Hayward, CA 94544

FAWP

Attn: Curtis H. Taylor

923 Old Bay Bridge Road

Tallahassee, FL 32303

Federal Conservation \& Renewable

Energy Referral Service

P. O. Box 8900

Silver Spring, MD 20907

Federal Energy Management Activities

CE 10.1

U.S. Department of Energy

1000 Independence Ave.

Washington, DC 20585

Florida Power Corp.

Attn: Christy Herig

3201 34th Street South

St. Petersburg, FL 33711
Florida Power and Light

Attn: R. S. Allan

P.O. Box 14000

Juno Beach, FL 33408

Florida Solar Energy Center D(4)

Attn: John Harrison

Library

David Block

Jim Huggins

300 State Road 401

Cape Canaveral, FL 32920

Georgia Inst. of Technology

Attn: Sheldon Jeter

School of Mechanical Engineering

Atlanta, GA 30332

Georgia Power Co.

Attn: Dennis Keebaugh

W. King

7 Solar Circle

Shenandoah, GA 30265

Gould Inc., Foil Division

Attn: David C. Knipfer, Sr. Mech. Engineer

2929 W. Chandler Blvd.

P.O. Box 190

Chandler, AZ 85244-0190

Harris Corporation (2)

Government Aerospace Systems Division

Attn: K. Schumacher

P. O. Box 9400

Melbourne, FL 32902

Hawai'i Energy Extension Service

Attn: Andrea Gill Beck

Dept. of Business and Economic Development

Hawai'i Business Center

99 Aupuni Street \#214

Hilo, HI 96720

Hawaii Solar Energy Association

Attn: Ron Richmond

P. O. Box 23350

Honolulu, HI 96823

Heliodyne, Inc.

Attn: Jurg H. Bieri, Ph.D.

4910 Seaport Ave.

Richmond, CA 94804 
Hilda Frazier DCA

2740 Centerview Drive

Tallahassee, FL 32399-2100

Hydrogen Engineering Associates

Attn: Roy E. McAlister

540 North May St., Suite 3078

Mesa, AZ 85201

Industrial Solar Technologies

Attn: Randy Gee

5775 West 52nd Ave.

Denver, CO 80212

International Planning Association, Inc

Editor

807 Caddington Ave.

Silver Spring, MD 20901

Jacksonville Electric Authority

Attn: George Rizk

Box 53105

Jacksonville, FL 32201

Jet Propulsion Laboratory

Attn: M. Alper

4800 Oak Grove Drive

Pasadena, CA 91109

Keamey \& Associates

Attn: David W. Kearney

14022 Condessa Drive

Del Mar, CA 92014

Kirk Enterprises, Inc.

Kirkland \& Richards Solar \& Elect.

Attn: Gregory H. Kirkland

P.O. Box 741

Inglis, FL 32649

Long Island Lighting Co.

Attn: Joseph Miller

175 E. Old Country Road

Hicksville, NY 11801

Los Alamos National Laboratory

Attn: Dr. Donald Neeper Staff Member

Advanced Engineering Technology Group

P.O. Box 1663, MS F576

Los Alamos, NM 87545
Lower Colorado River Resource

Conservation \& Development Project

Attn: Michael Forrest

Coordinator

Parker,

Massachusetts Institute of Technology

Attn: J. G. Kassalkian

M. F. Schlect

Elec Powicr Systems Engr. Lab.

Cambridgs, MA 02139

Mechanical Technology, Inc.

Attn: G. R. Dochat

968 Albany Shaker Road

Latham, NY 12110

Meridian Corporation (2)

Attn: D. Kumar

Anil Cabraal

4300 King Street, Suite 400

Alexandria, VA 22302-1508

MicroGrid, Inc.

Attn: Terry L. Egnor

500 N.E. Multmomah, Suite 1050

Portland, OR 97232

Midwest Research Institute

Attn: $\quad$ R. L. Martin

425 Volker Blvd.

Kansas City, MO 64110

NASA/Lewis Research Center

Attn: R. Corrigan Richard DeLombard

21000 Brookpark Road

Cleveland, $\mathrm{OH} 44135$

National Renewable Energy Lab (5)

Attn: James G. Jones

Russ Hewett

T. Williams

L. M. Murphy

Steve Rubin

1617 Cole Blvd.

Golden, CO 80401-3393

National Technology Transfer Center

Attn: Sergio Lopes

Wheeling Jesuit College

Wheeling, WV 26003 
Natural Power, Inc.

Attn: Brian Gordon

Francestowid Turnpike

New Boston, NH 0.3070

Nature Conservancy

Attn: Will Murray

1815 N. Lynn Street

Arlington, VA 22209

Naval Civil Engineering Lab

Attn: Kwang Ta Huang

CODE L 72

Port Hueneme, CA 93043

Nebraska Department of Economic Development

Attn: Rex Martin

University of Nebraska-Lincoln

WI9I Nebraska Hall

Lincoln, NF 68588-0535

New England Power Service

Attn: Ed Gulachenski

25 Research Drive

Westborour', MA 0158i

New Mexico Electric Cooperative

Attn: Robert E. Castillo

Exec Itive Vice President

614 Don Gaspar

Santa Fe, NM 87501

New Mexico Institute of Mining \& Techn $>$ logy

Attn: Joe Galun Associate Director of Engineering

Physical Plant Department

Campus Station

Socorro, NM 87801

New Mexico League of Women Voters

Attn: Barbara M. Rosnagle

Natural Resources Chair

116 Salamanc3, N.W.

Albuquerque, NM 87107

New Mexico Manufacturing Productivity Center

Attn: Graham Bartlett

1009 Bradbury Drive, S.E.

Albuquerque, NM 87106

New Mexico Public Service Commission

Attn: Peter B̈icikiey

224 E. Palace Avenue

Santa Fe, NM 87501-2031
New Mexico R\&D Forum

University of New Mexico

Attn: Richard Cole

Director

R\&D Communication Office

Albuquerque, NM 87131-6076

New Mexico Energy Industries Association

Attm: Tom Volek

P.O. Box 90275

Albuqurque, NM 87199-02175

New Mexico Solar Energy Institure

New Mexico State University

Box 3 SOL

Las Cruces, NM 88003

New Mexico State University

Attn: Nick Deveraux

Astronomy Department

Box 30001 , Dept. 4500

Las Cruces, NM 88003

New Mexico State University

Attn: Pat Melendrez

San Miguel County Extension Agent

P.O. Box 2170, West Branch

Las Vegas, NM 87701

New Mexico State University (3)

Southwest Technology Development Institute

Attn: Steve Durand

Andrew L. Rosenthal

Dr. Rudi Schoenmackers

Box 30001, Dept. 3SOL

Las Cruces, NM 88003-0001

New Mexico State Unversity

Cooperative Extension Service

Attn: Rob ert O. Coppedge, Ph.D.

Box 3AE

Las Cruces, NM 88003

New York State Energy Research and Dev. Authority

Attn: Fred Strnisa

2 ? ockefeller Plaza

Albany, NY 12223

New York State Pub. Serv. Comm.

Attn: Edward Schrom

Empire State Plaza

Albany, NY 12223 
Nippon Electric Glass Co., Ltd. Attn: Bernard L. Steierman 11801 Rockville Pike, Suite 1704 Rockville, MD 20852

\author{
North Carolina Altemative \\ Energy Corp. \\ Atm: Bob Weiss \\ P.O. Box 12699 \\ Research Triangle Park, NC 27709 \\ Northern Research \& Eng. Corp \\ Attn: Dr. James B. Kesseli \\ 39 Olympia Avenue \\ Woburn, MA 01801-2073
}

Northwest Power Planning Council

Attn: Tom Truelove

851 S.W. Sixth Ave., Suite 1100

Portland, Oregon 97204

Pacific Gas and Electric Co. (4)

Attn: Steve Hester

G. Braun

3400 Crow Canyon Road

San Ramon, CA 94583

Parsons of California

Attn: D. R. Biddle

P.O. Box 6189

Stockton, CA 95206

Pennsylvania Energy Office

Attn: Dr. Phillip Schuller, Associate Director

116 Pine Street

Harrisburg, PA 17101-1227

Photovoltaic Energy Systems

Attn: Paul Maycock

P. O. Box 290

Casanova, VA 22017

Platte River Power Authority

Attn: Carol Dollard

Timberline, and Horsetooth Roads

Fort Collins, CO 80525

Portland State University

Attn: Jean P. Murray, Ph.D.

P.O. Box 751

Portland, OR 97207-0751
Power Kinetics, Inc.

Attn: W. E. Rogers

415 River Street

Troy, NY 12180-2822

Public Service Co. of New Mexico

Attn: Becky Kilbourne

Retail Electric Marketing Center

Alvarado Square

Albuquerque, NM 87158

Public Service Co. of New Mexico

Attn: Vic Silva

CR Dept. (0076)

Alvarado Square

Albuquerque, NM 87158

Radco Products, Inc.

Attu: George O. Radford

President

2877 Industrial Parkway

Santa Maria, CA 93455

Renewable Energy Institute

Attn: Kevin Porter

1001 Connecticut Avenue NW

Suite 719

Washington, DC 20036

Research Triangle Institute

Attn: Carl Parker

P.O. Box 12194

Research Triangle Park, NC 27709

Roan Corporation

Attn: James L. Abolt

177 Bovet Road, Suite 520

San Mateo, CA 94402

Rockwell International Corporation Energy Technology Engineering Center Attn: Robert K. Hoside, C.E.M.

P. O. Box 1449

Canoga Park, CA 91304

Rockwell International Space Station Systems Division Attn: I. M. Chen 12214 Lakewood Blvd. Downey, CA 90241 
San Diego Gas \& Electric Co.

Attn: Skip Fralick

P.O. Box 1831

San Diego, CA 92112

Schofield Solar

Attn: Allen Carrozza

2450 Channel Drive, Suite A

Venture, CA 93003

Science and Technology Corporation

Attn: Ronald J. Nelson

12452 Towner, N.E.

Albuquerque, NM 87112

Science Applications Intemational Corp.

Attn: Barry Butler

Mail Stop 32

10260 Campus Point Court

San Diego, CA 92121

Scientific Analysis, Inc.

Attn: John Ailen Gunn, PE

6012 E. Shirley Lane

Montgomery, AL 36117

Seldom Seen Education

Attn: Mary C. Stuever

P.O. Box 474

Placitas, NM 87043

Sierra Club Rio Grande Chapter

Attn: Ken Hughes Energy Chair]

1204 Placita Loma

Santa Fe, NM 87520

Sierra Pacific Power Co.

Attn: R. G. Richards

P. O. Box 10100

Reno, NV 89520

SMUD

Attn: Don Osborne

Box 15830

Sacramento, CA 95852-1830

Solar Development, Inc.

Attn: David Burrows

3630 Reese Avenue

Garden Industrial Park

Riviera Beach, FL 33404
Solar Energy Corporation

Attn: Robert Aresty

Box 3065

Princeton, NJ 08540

Solar Energy Industries Association

Attn: Ken Sheinkopf

S. Sklar

Linda Ladas

777 N. Capitol St., N.E., Suite 805

Washington, DC 20002-4226]

Solar Kinetics, Inc.

Attn: J. A. Hutchison

P.O. Box 540636

Dallas, TX 75354-0636

Solar Power Engineering Co. Inc.

Attn: T. Buna

P. O. Box 91

H. Wroton

Morrison, CO 80468

Solar Steam

Attn: D. E. Wood

P.O. Box 32

Fox Island, WA 98333

Southern California Edison Co.

Attn: C. Lopez

P.O. Box 800

Rosemead, CA 91770

Southern Company Services, Inc.

Attn: J. Timothy Petty

P.O. Box 2625

Birmingham, AL 35202

Southwest Technology Development Institute

Attn: Robert Smith, M.E.

- Property Control Division

General Services Department

Simms Building

715 Alta Vista

Santa Fe, NM 87503

SRS Technologies

Attn: R. Bradford

990 Explorer Blvd., NW

Huntsville, AL 35806 
State of Califormia

Califomia Energy Commission

Energy Technology Development Division

Research and Development Office

Attn: Promod Kulkarni

Phil Misemer

15169 th Street, MS-43

Sacramento, CA 95814-5512

State of California

California Energy Commission

Attn: Alec Jenkins

1516 - 9th Street

Sacramento, CA 95814-5512

State of California

Department of Corrections

Attn: Harry Franey

3116 Pleasant Grove Road

Pleasant Grove, CA 95668

State of Colorado

Office of Energy Conservation

Attn: Howard "Andy" Walker, Ph.D., M.E. Renewable Energies Coordinator

1675 Broadway, Suite 1300

Denver, CO 80202-4613

State of Florida

Attn: Daryl O'Connor

Executive Office of the Governor

The Capitol

Tallahassee, FL 32399-0001

State of Florida

Colleen McCann Kettles

Attn: David Block

Jim Huggins

Florida Solar Energy Center

300 State Road 401

Cape Canaveral, FL $32920-4099$

State of Hawaii

Attn: David A. Rezachek, Ph.D., P.E.

Maurice H. Kaya, P.E.

Dept. of Business and Economic Development 335 Merchant St.

Honolulu, HI 96813
State of New Mexico

Energy Information Services

Energy, Minerals and Natural Resources Dept.

Attn: Ingrid Kelley

2040 South Pacheco Street

Santa Fe, NM 87505

State of New Mexico

Energy, Minerals and Natural Resources Dept.

Atin: James Cannon

Anita Lockwood

Harold Trujillo]

Brian K. Johnson, P.E.

2040 South Pacheco Street

Santa Fe, NM 87505

State of New Mexico

Energy, Minerals and Natural Resources Dept.

Attn: Judy Kowalski

Director of Recycling Programs

2040 South Pacheco Street

Santa Fe, NM 87505

State University of New York

Atmospheric Sciences Research Center

Attn: R. Perey

Albany, NY 12222

State of Texas

Department of Commerce

Attn: Charles Nichols

Renewable Energy Market

Development Specialist

Office of Advanced Technology

P.O. Box 12728

Austin, TX 78711

Sterling Grogan, Ecologist

3128-2 Glenwood Drive

Albuquerque, NM 87107

Stearns-Catalytic Corp.

Attn: T. E. Olson

Box 5888

Denver, CO 80217

Sun Exploration and Production Co.

Attn: R. I. Benner

P.O. Box 2880

Dallas, TX 75221-2880 
Sun Utility Network, Inc.

Attn: Les Hamasala

510 W. Gth St., Suite 417

Los Angeles, CA 90014

Sunshine Solar, Inc.

Attn: Steven R. Robbins, President 9916 SW 218 Terr.

Miami, FL 33190

Technology Enterprise Division

Attn: Karen Martin

P. O. Box 549

Mesilla, NM 88046

Tennassee Valley Authority

Attn: Sharon Ogle

Solar Applications Branch

B 513 Signal Place

Chattanooga, TN 37401

The Amorial Bearings of Tuthill

Education/Development

Attn: Jerry Tuttle, Ph.D.

12305 Eastridge Drive, N.E.

Albuquerque, NM 87112

The Energy Foundation

Attn: Bill Keepin

75 Federal Street

San Francisco, CA 94107

The Solar Letter

Attn: Allan L. Frank

9124 Bradford Rd.

Silver Spring, MD 20901-4918

Thermomotor Corporation

Attn: Lee Fellows

Stirling Engine Research \& Development

P. O. Box 201207

Austin, TX 78720

Tom Brumleve

1512 Northgate Road

Walnut Creek, CA 94598

U.S. Army Corps of Engineers

Attn: Larry D. Lister Mechanical Engineer

P.O. Box 4005

Champaign, IL 61720-1305
U.S. Ammy Engineering and Housing

Support Center

Attn: Rober G. O'Brien, P.E.

CEHSC-FU

Chief Utilities Engineering Division

Fort Belvoir, VA $22060-5580$

U.S. Department of Energy (4)

Forrestal Building

Attn: G. Burch

N. Hough

S. Gronich

Code EE-13

C. Carwile

1000 Independence Avenue, SW

Washington, DC 20585

U.S. Department of Energy

San Francisco Operations Office

Attn: R. Hughey

1333 Broadway

Oakland, CA 94612

U.S. Department of Energy

Forrestal Building

Attn: R. Annan

Code EE-13

1000 Independenc Avenue, SW

Washington, DC 20585

U.S. Department of Energy (2)

Albuquerque Operations Offices

Attn: N. Lackey

P. O. Box 5400

Albuquerque, NM 8715

Unique Mobility Inc.

Attn: William M. Anderson

3700 South Jason St.

Englewood, CO 80110

United Solar Technologies, Inc.

Attn: Richard Kelly

3434 Martin Way, Suite One

Olympia, WA 98506

University of Chicago

Enrico Fermi Institute

Attn: J. O'Gallagher

5640 Ellis Avenue

Chicago, IL 60637 
University of Central Florida

Attn: Dr. Gerard G. Ventre Research Scientist

Institute for Simulation and Training

12324 Research Parkway, Suite 300

Orland, FL 32826

University of Delaware

Attn: Allen Bamett

Dept. of EE

Newark, DE 19711

University of Hawaii

Attn: Patrick Takahashi

Hawaii Naturai Energy Inst.

2540 Dole Street

Honolulu, HI 96822

University of Lowell

Attn: Thomas Costello Fahd Wakim

1 University Avenue

Lowell, MA 01854

University of Nevada at Las Vegas

Attn: B. Boehm

Mechanical Engineering Department

Las Vegas, NM 89154

University of New Mexico

NMREI

Attn: G. Leigh

Albuquerque, NM 87131

University of New Mexico

Attn: M. W. Wildin

Department of Mechanical Engineering

Albuquerque, NM 87131

USAF/ETAC

Attn: Hilda Snelling

ENGRC Meteorology Section

Scott AFB, IL 62225

Ventures Plus, Inc.

Attn: Frank A. Simko

4123 N. Tamiami Trail

Sarasota, F1 34234
Virginia Polytechnic Inst. and State University

Attn: Saifur Rahman, Ph.D.

Associate Professor

Electrical Engineering Department

Blacksburg, VA 24061

Wall Street Jounral

Attn: David Stipp,

Environmental reporter

10 Post Office Square

Suite 715

Boston, MA 02109

Westinghouse Science \& Tech. Ctr.

Attn: Walter J. Dollard Technology Director

Energy \& Utility Systems Group

1310 Buelah Rd.

Pittsburg, PA 15235

Zomeworks

1011A Sawmill Road, N.W.

Albuquerque, NM 87104

\section{EOREIGN}

Australian National University Department of Engineering Physics Attn: Prof. Stephen Kaneff

P.O. Box 4

Canberra ACT 2600, AUSTRALIA

DLR

Institute for Technical Thermodynamics Attn: R. Buck

Pfaffenwaldring 38-40

7000 Stuttgart 80, GERMANY

Energy Research Centre (2)

Attn: K. Inall

R. S. Phy. Sc.

Australian National University

Canberra ACT 2601

AUSTRALIA

$\begin{array}{ll}\text { Intermal } & \text { Distribution } \\ \mathbf{4 2 1 2} & \text { M. Allen } \\ \mathbf{4 2 1 2} & \text { R. Hamil } \\ \mathbf{4 2 1 2} & \text { D. Belasich }\end{array}$




\begin{tabular}{ll}
4212 & C. Lombawa \\
6000 & D. L. Hartley \\
6200 & D. E. Arvizu \\
6200 & A. VanArsdall \\
6201 & P. C. Klimas \\
6202 & G. J. Jones \\
6213 & T. C. Bickel \\
6215 & C. P. Cameron \\
6215 & R. M. Edgar \\
6215 & M. E. Ralph \\
6215 & E. E. Rush \\
6215 & J. W. Strachan \\
6216 & C. E. Tyner \\
6216 & J. R. Anderson \\
6216 & L. R. Evans \\
6216 & T. R. Mancini \\
6216 & D. F. Menicucci (20) \\
6218 & D. E. Hasti \\
6218 & R. R. Hill \\
6218 & R. C. Pate \\
6218 & H. N. Post \\
6218 & J. W. Stevens \\
7141 & S. A. Landenberger (5) \\
7145 & Document Processing DOE/OSTI (8) \\
7151 & G. C. Claycomb \\
7841 & R. Wrons \\
8523 & Central Technical Files \\
\hline &
\end{tabular}



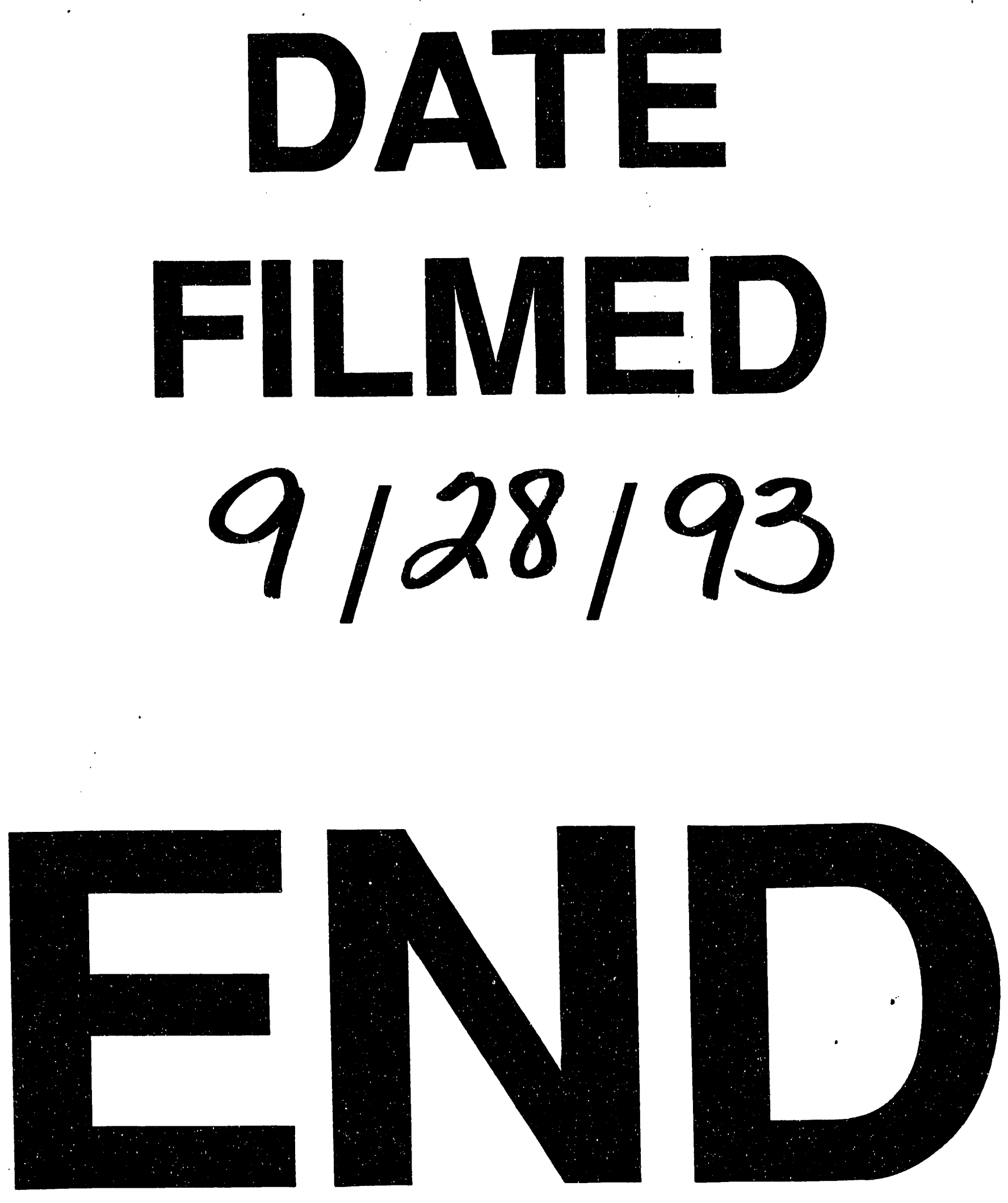
